\title{
Review
}

\section{Apoptosis signaling by death receptors}

\author{
Klaus SCHULZE-OSTHOFF ${ }^{1}$, Davide FERRARI ${ }^{1}$, Marek LOS $^{1}$, Sebastian WESSELBORG ${ }^{1}$ and Marcus E. PETER \\ ${ }^{1}$ Department of Internal Medicine I, Medical Clinics, University of Tübingen, Germany \\ 2 Tumor Immunology Program, German Cancer Research Center, Heidelberg, Germany
}

(Received 16 February/25 March 1998) - EJB 98 0228/0

Death receptors have been recently identified as a subgroup of the TNF-receptor superfamily with a predominant function in induction of apoptosis. The receptors are characterized by an intracellular region, called the death domain, which is required for the transmission of the cytotoxic signal. Currently, five different such death receptors are known including tumor necrosis factor (TNF) receptor-1, CD95 (Fas/ APO-1), TNF-receptor-related apoptosis-mediated protein (TRAMP) and TNF-related apoptosis-inducing ligand (TRAIL) receptor-1 and -2 . The signaling pathways by which these receptors induce apoptosis are rather similar. Ligand binding induces receptor oligomerization, followed by the recruitment of an adaptor protein to the death domain through homophilic interaction. The adaptor protein then binds a proximal caspase, thereby connecting receptor signaling to the apoptotic effector machinery. In addition, further pathways have been linked to death receptor-mediated apoptosis, such as sphingomyelinases, JNK kinases and oxidative stress. These pro-apoptotic signals are counteracted by several mechanisms which inhibit apoptosis at different levels. This review summarizes the current and rapidly expanding knowledge about the biological functions of death receptors and the mechanisms to trigger or to counteract cell death.

Keywords: apoptosis; Bcl-2; caspase; CD95 (APO-1/Fas); death receptor; inhibitor of apoptosis protein; nuclear factor- $\kappa \mathrm{B}$; tumor-necrosis factor; tumor-necrosis-factor-related apoptosis-inducing ligand; tumornecrosis-factor-receptor-related apoptosis-mediating protein.

Apoptosis or programmed cell death is the innate mechanism by which the organism eliminates unwanted cells. In contrast to necrosis, apoptosis is the most common physiological form of cell death and occurs during embryonic development, tissue re-

Correspondence to K. Schulze-Osthoff, Department of Internal Medicine I, Medical Clinics, Eberhard-Karls-University, Otfried-MüllerStr. 10, D-72076 Tübingen, Germany

Fax: +497071295865.

E-mail: schulze-osthoff@uni-tuebingen.de

Abbreviations. AICD, activation-induced cell death; Apaf, apoptotic protease-activating factor; CAD, caspase-activated DNase; CARD, caspase recruitment domain; CD95L, CD95 ligand; CrmA, cytokine response modifier A; DcR, decoy receptor; DD, death domain; DED death effector domain; DR, death receptor; DISC, death-inducing signaling complex; FADD, Fas-associated death domain protein; FAN, factorassociated neutral sphingomyelinase; FAP; Fas-associated phosphatase; FLICE, FADD-like ICE; FLIP, FLICE-inhibitory protein; IAP, inhibitor of apoptosis protein; ICE, interleukin-1 $\beta$-converting enzyme; JNK, cJun N-terminal kinase; LT, lymphotoxin; MADD, mitogen-activated kinase activating death domain protein; MAP, mitogen-activated protein; mTNF, membrane-bound TNF; NF- $\kappa \mathrm{B}$, nuclear factor-kappa B; PAK, p21-activated kinase; PARP, poly(ADP-ribose) polymerase; RAIDD, RIP-associated ICH-1/Ced-3 homologous death domain protein; RIP, receptor-interacting protein; SAPK, stress-activated protein kinase; SMase, sphingomyelinase; sTNF, soluble TNF; TNF, tumor necrosis factor; TNF-R, TNF receptor; TRADD, TNF receptor-associated death domain protein; TRAF, TNF receptor-associated factor; TRAIL, TNFrelated apoptosis-inducing ligand; TRAMP, TNF receptor-related apoptosis-mediating protein.

Note. This Review will be reprinted in EJB Reviews 1998 which will be available in April 1999. modelling, immune regulation and tumor regression. Cells undergoing apoptosis show a sequence of cardinal morphological features including membrane blebbing, cellular shrinkage and condensation of chromatin. Biochemically, these alterations are associated with the translocation of phosphatidylserine to the outer leaflet of the plasma membrane and the activation of an endonuclease which cleaves genomic DNA into multiples of internucleosomal fragments. In contrast, necrosis is classically induced following traumatic injury or exposure to high concentrations of noxious agents. Irreversible damage of the plasma membrane, mitochondrial dysfunction and cell lysis are characteristic for necrotic cell death.

Higher organisms have developed several mechanisms to rapidly and selectively eliminate cells by apoptosis. A fine-tuned mechanism to regulate life and death of a cell is the interaction of surface receptors with their cognate ligands. Several receptors are able to transmit cytotoxic signals into the cytoplasm, but in most cases they have a wide range of other functions unrelated to cell death, such as induction of cell activation, differentiation and proliferation. Whether the signals induced by a given receptor lead to cell activation or death is highly cell-type specific and tightly regulated during differentiation. For example, TNF receptors can exert co-stimulatory signals for proliferation of naive lymphocytes as well as inducing death signals required for deletion of activated lymphocytes.

Many receptors with important functions in differentiation, survival and cell death belong to an emerging family of structurally related molecules, called the TNF receptor superfamily. For some members of the family an apoptosis-inducing activity has 


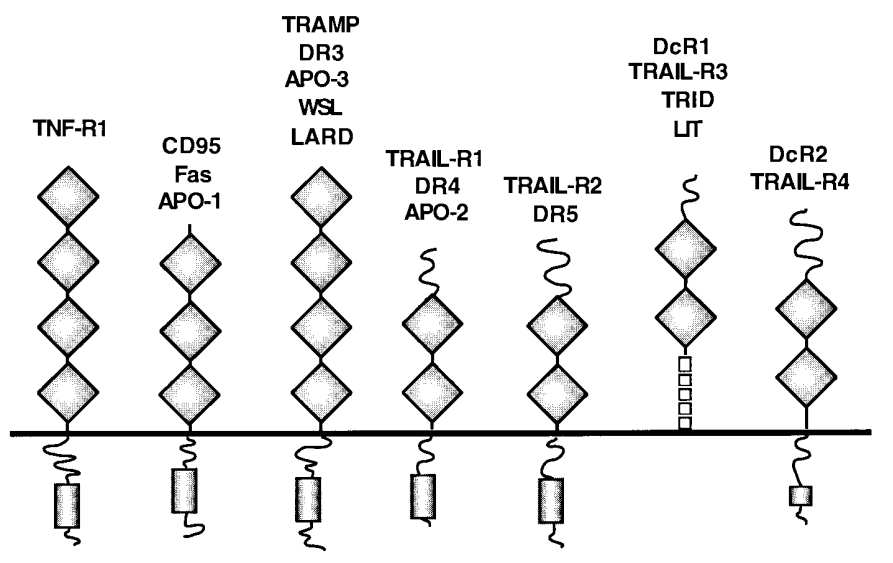

Fig. 1. Schematic representation of the death receptors. Members of this subgroup of the TNF receptor superfamily are characterized by the intracellular death domain, depicted as a gray box. The two to four boxes in the extracellular part represent similar Cys-rich domains. The TRAIL decoy receptors DcR1 and DcR2 lack an intracellular tail or contain a truncated non-functional death domain.

been reported. However, most of them also have other functions such as induction of proliferation, differentiation, immune regulation and gene expression. Receptors with pleiotropic functions include TNF-R1, TNF-R2, NGF-R, CD27, CD30, CD40, OX40, NGF-R, TRAMP (DR3/wsl-1/APO-3/LARD), HVEM (ATAR/TR2), GITR and RANK (for references see [1-3]). These receptors are type I membrane proteins which are structurally similar. Each possesses in its extracellular domain twosix imperfect repeats of about 40 amino acids, with each of approximately six Cys residues. Their cytoplasmic domains generally lack considerable sequence similarity.

APO-1/Fas, now called CD95, was the first member of the TNF receptor superfamily described in terms of its function in apoptosis $[4,5]$. Sequence comparison of the intracellular domain of CD95 with TNF-R1 revealed that both receptors contained a similar stretch of about 80 amino acids. This region has been designated the death domain (DD) since it enables transmission of a cytotoxic signal by both molecules [6,7]. Recent similarity searches in EST databases led to the cloning of a number of novel membrane receptors that contain such a death domain and are therefore referred to as the death receptors (DRs) (Fig. 1). TRAMP (DR3/wsl-1/APO-3/LARD), is both structurally and functionally similar to TNF-R 1 and is abundantly expressed in T-lymphocytes [2, 8-11]. TRAIL-R1 (DR4, APO-2) and TRAIL-R2 (DR5) have been found as receptors binding to a novel cytokine, called TRAIL for TNF-related apoptosis-inducing ligand. The two TRAIL receptors are functionally similar to CD95 as their main function seems to be to induce apoptosis [12-18]. The TRAIL system, in addition, consists of two neutralizing decoy receptors, called DcR1 (TRAIL-R3, TRID, LIT) and DcR2 (TRAIL-R4) [13-16, 19-22]. The sequence of DcR1 encodes a protein that contains the external TRAIL-binding region as well as a stretch of amino acids that anchors the receptor to the membrane. But, unlike the other receptors, DcR1 lacks an intracellular tail needed to spark the death pathway. DcR2 is also able to bind TRAIL but contains a truncated death domain. Thus, both decoy receptors will prevent TRAIL from engaging functional TRAIL receptors and thereby render cells resistant to apoptosis. Collectively, this underlines that the death domain is required to induce apoptosis triggered by the different surface receptors.

For most members of the TNF-R superfamily their cognate ligands have been identified. Four of them, CD95L, TNF, lym- photoxin- $\alpha(\mathrm{LT} \alpha, \mathrm{TNF} \beta)$ and TRAIL bind to death receptors [23, 24]. It was not surprising to find that, in addition to the receptors, also the ligands display structural similarities, which are reflected by similar mechanisms of receptor recognition and triggering. The ligands recognize their receptors through a shared structure composed of anti-parallel $\beta$-sheets arranged in a jelly roll structure. As supported by structural and biochemical data, it is believed that all active ligands consist of three identical subunits and activate their receptors by oligomerization [2528]. Another common feature of the ligands is that almost all of them are type II transmembrane proteins. The only exception is LT $\alpha$ which, although formed as a soluble protein, binds to membrane-bound LT $\beta$ and thereby also acts as a cell-bound form. Lymphotoxins can be found as homotrimers $\left(\mathrm{LT} \alpha_{3}\right)$ or heterotrimers $\left(\mathrm{LT} \alpha_{1} / \beta_{2}\right.$ or $\left.\mathrm{LT} \alpha_{2} / \beta_{1}\right)$. The $\mathrm{LT} \alpha$ homotrimer binds the TNF receptors, whereas the heterotrimers bind to the LT $\beta$ receptor which does not contain a death domain. Although TNF-related ligands are synthesized as membrane-bound molecules, most of them also exist as soluble forms. The secreted forms are generated by rather specific metalloproteases. For TNF, a zincdependent metalloprotease, called TACE (TNF $\alpha$-converting enzyme) was recently cloned and shown to specifically cleave TNF $[29,30]$.

\section{Biological functions of death receptors}

TNF was isolated more than 15 years ago, based on its ability to kill tumor cells in vitro and to cause hemorrhagic necrosis of a transplantable tumor (MethA sarcoma) in mice. Because TNF proved to be highly toxic in animals and humans, it did not fulfill initial expectations in the treatment of cancer. Considerable evidence suggests that inappropriate expression of TNF plays a crucial role in various acute and chronic inflammatory disorders (reviewed in [31-34]). The CD95 (APO-1, Fas) molecule has been identified much later as a cell surface receptor that could mediate apoptotic cell death of transformed cells $[35,36]$. Agonistic antibodies that were specific to human CD95 were able to cause regression of experimental human tumors growing in nude mice [35]. Although due to the high systemic side effects, application of CD95-mediated apoptosis has also not held its promise as a potential cancer therapy, some evidence has now documented a pivotal role of CD95 in various physiological and pathological forms of cell death [37-39]. Finally, TRAIL and its different receptors have been identified as a novel complex receptor/ligand system. TRAIL is able to induce apoptosis in many transformed cells. In contrast to TNF and CD95L, no side effects of TRAIL on normal primary cells have yet been reported. Thus, whether the TRAIL pathway represents the long-sought-after means to selectively kill tumor cells remains to be shown. In the following, we will describe the relevance and some biological functions of these receptors within the organism. Although most functions have been described in the immune system, death receptors are involved in a number of very different apoptotic settings ranging from cell homeostasis, organ development, immune privilege and anticancer treatment.

The CD95 system. Our understanding of the function of the CD95 receptor and its ligand has been mainly elucidated by the finding that both molecules are mutated in mouse strains suffering from severe autoimmune diseases. lpr (for lymphoproliferation) mice, which lack a functional CD95 receptor, as well as gld (for generalized lymphoproliferative disease) mice, which bear a mutant CD95, ligand exhibit various autoimmune phenomena resembling systemic lupus erythematosus in humans $[40,41]$. Both mouse strains produce autoantibodies and accumulate $\mathrm{CD}^{-} \mathrm{CD}^{-} \mathrm{T}$ cells leading to lymphadenopathy, spleno- 
megaly and other signs of autoimmune disorders. The gld defect arises from a point mutation within the CD95L gene, changing an amino acid critical for CD95 binding. The lpr mutation is caused by the insertion of a transposable element into intron 2 of the CD95 gene, thereby preventing full-length transcription [42]. Recently, in humans a similar disease with a dysfunction of CD95 was reported [43-45]. Children with autoimmune lymphoproliferative syndrome (ALPS), also called Canale-Smith syndrome, have massive nonmalignant lymphadenopathy, hepatosplenomegaly, altered $\mathrm{T}$ cell populations and other manifestations of systemic autoimmunity. The loss-of-function phenotype in mouse and man indicates that CD95 plays an important role in the regulation of the immune response and maintenance of self-tolerance.

Molecular studies provided evidence that CD95 is the mediator of activation-induced cell death (AICD), a form of apoptosis important for the downsizing of the immune response, as well as an effector of cytotoxic T-cell activity [46-50]. In contrast, there is no convincing evidence that CD95 is involved in negative selection. This assumption is consistent with a relatively normal thymic architecture and proper thymic deletion of activated T cells in $l p r$ mice [51, 52]. $l p r$ and gld mice further show B-cell hyperreactivity associated with the production of autoantibodies, suggesting that CD95 also controls the expansion of the B-cell compartment (reviewed in [37, 53]).

Just as a defect of the CD95 system is intimately linked to autoimmune diseases caused by the impaired removal of autoreactive lymphocytes, so may inappropriate induction of apoptosis lead to pathological conditions. Evidence exists that CD95 is critically involved in the progression of viral diseases, such as HIV-1 or hepatitis B virus infections where massive apoptosis occurs. It was shown that indirect mechanisms lead to a sensitization of noninfected T-cells towards AICD after HIV-1 infection $[54,55]$. T-lymphocytes from HIV-1-infected patients exhibit an elevated expression of CD95 and sensitivity towards CD95-mediated apoptosis [56, 57]. Two HIV-1-derived proteins, gp120 and Tat, have been found to activate the expression of CD95L in T-lymphocytes [54]. This process may cause fratricide or suicide death of uninfected T-lymphocytes and result in the continuous depletion of $\mathrm{CD}^{+}{ }^{+} \mathrm{T}$-cells during AIDS disease.

Although CD95L was originally found on activated T-lymphocytes, various other non-lymphoid cells can express it. A high constitutive expression is detected in Sertoli cells of the testis and epithelial cells of the anterior eye chamber [58-60]. This finding led to the proposal that CD95L is responsible for the maintenance of immune privilege, which characterizes the ability of certain organs to suppress graft rejection, even when transplanted in non-matched individuals. After viral inoculation into the anterior eye chamber, infiltrating lymphocytes and granulocytes are eliminated probably due to high expression of CD95L $[58,60]$. This apoptosis is not observed in eyes of animals with defective CD95L ( gld mice), and the resulting inflammation destroys the tissue. Thus, CD95L is necessary for the maintenance of the privileged status by killing infiltrating lymphocytes of the host.

The function of CD95 in immune privilege has presumably enormous implications for future transplantation strategies aimed to avoid allograft rejection. It was recently shown that human corneas express functional CD95L [61], raising the possibility that this molecule could act to protect cornea grafts. Examination of corneal transplants in mice supported this idea; while approximately $45 \%$ of allogeneic cornea transplants survived for an extended period, no graft survival was seen with corneas expressing defective CD95 receptor or ligand. A protective effect of CD95L was observed after transplantation of allogeneic testis under the kidney capsule [59]. Furthermore, myo- blasts expressing ectopic CD95L protected allogeneic pancreatic islets co-implanted under the kidney capsule of animals with streptozotocin-induced diabetes [62]. These grafts, which were quickly rejected if myoblasts did not express CD95L, maintained their function for an extended period of time. Consistent with this was the observation that allogeneic islets showed delayed rejection when co-implanted with CD95L-expressing testis tissue [63].

CD95L-mediated depletion of cytotoxic T-lymphocytes may not only be beneficial but may also play a role for tumor cells to escape the host's immunosurveillance. Recently, high-constitutive CD95L expression has been found in distinct lineages of tumors, such as colon, lung, renal carcinoma, melanoma, hepatocellular carcinoma, astrocytoma and T- and B-cell-derived neoplasms [64-70]. This suggested that the same mechanisms responsible for protecting tissues from autoimmune destruction may be also used by tumors in eliminating activated lymphocytes that attempt to attack tumor cells.

However, there are some conditions where the presence of CD95L may not be involved in immunosuppression but rather associated with inflammatory tissue damage. A role of CD95Linduced apoptosis has been, for instance, implicated in alcoholinduced hepatitis, graft-versus-host disease and autoimmune diseases, such as diabetes and encephalomyelitis [71-75]. Allison et al. [76] reported that transgenic expression of CD95L in pancreatic islets failed to protect these from allogeneic transplant rejection when placed under the kidney capsule. The presence of CD95L rather induced a granulocytic infiltrate, which is related to a report showing that $\mathrm{CD} 95 \mathrm{~L}$ on tumor cells can induce a rejection reaction [77]. In these cases, CD95L expression causes tissue damage directly, or indirectly by recruitment of granulocytes. Indeed, it has been found that CD95 ligation can result in secretion of the chemokine IL-8 [78]. In conjunction with T-cell receptor activation, CD95 may act as a costimulatory molecule, enhancing gene expression of IL-2 and other cytokines [79]. In addition, some cell types respond to CD95 ligation via proliferation and not cell death [79-82]. However, the overall in vitro and in vivo data suggest that CD95 is a receptor which mainly mediates apoptosis. This is reflected by the observation that, in contrast to TNF, CD95 does not induce the activation of proinflammatory transcription factors, including NF- $\kappa \mathrm{B}$, AP-1 or NF-AT [83].

A particular function of CD95 was identified in the thyroid gland. Normal thyrocytes constitutively express functional CD95 ligand but do not express the receptor. However, in Hashimoto's thyroiditis patients, thyrocytes do express CD95, and these cells undergo apoptosis [84]. Hence, in Hashimoto's thyroiditis the normally protective function of $\mathrm{CD} 95 \mathrm{~L}$ on thyrocytes leads to the destruction of the thyroid gland.

An exciting finding was further that several unrelated deathinducing agents and conditions obviously utilize physiological means of induction of apoptosis. Apoptosis mediated by p53 may involve CD95, as its gene has been found to be a target of this transcription factor [85]. Also overexpression of the c-Myc, which induces cell death under growth-limiting conditions, appears to mediate death, at least partially, by a mechanism requiring CD95/CD95L interaction [86]. An apoptosis-inducing effect of c-Myc was not observed in $l p r$ and gld mice. Furthermore, AICD in T-lymphocytes is blocked by c-Myc antisense oligonucleotides [87]. The mechanism by which c-Myc sensitizes cells for CD95-mediated apoptosis remains to be elucidated.

Recent data demonstrate that anticancer-drug-induced cell death may involve the CD95 system. Several different drugs widely used in chemotherapy of cancers induce CD95L expression in leukemic, hepatocellular and neuroblastoma cells [8890]. Because drug-induced cell death could be inhibited by 
CD95L neutralizing reagents, it was proposed that binding of CD95L to the receptor then triggers the apoptosis cascade in chemosensitive tumor cells. The up-regulation of CD95L may therefore provide a new idea about the mechanism of action of chemotherapy. It should be pointed out, however, that the involvement of CD95 in this scenario is rather controversial, as some investigators found no different susceptibility between CD95-sensitive and resistant tumor cells [91, 92].

An interesting situation has been found in cell death induced by ultraviolet irradiation. Ultraviolet-induced apoptosis is strongly attenuated in CD95-resistant keratinocytes [93, 94]. It has been shown that the irradiation directly oligomerizes and thereby activates death receptors, such as CD95 and TNF-R1. This is presumably mediated by energy transfer which induces a conformational change of the receptors. This type of apoptosis therefore does not require CD95L expression, but directly engages the CD95 signaling pathway. Altogether, these findings demonstrate that CD95 plays a role in very diverse apoptosis settings.

\section{The TNF system}

In contrast to the CD95, the biological function of the TNF system is more complex. In addition to its cytotoxicity, TNF exerts a number of other activities related to proinflammatory processes on almost all cell types (reviewed in [31-34]). The function of TNF is also complicated by the the presence of two different TNF receptors, TNF-R1 and TNF-R2, which can be occupied by two different ligands. TNF and the LT $\alpha$ homotrimer bind to the TNF receptors, while $\mathrm{LT} \alpha / \mathrm{LT} \beta$ complexes selectively ligate the $\mathrm{LT} \beta$ receptor.

TNF was originally found as a factor in endotoxin-primed mice which caused hemorrhagic necrosis of transplanted tumors [95]. It was also identified as a catabolic substance that suppressed the expression of lipoprotein lipase and other anabolizing enzymes and was therefore termed cachectin [96]. A major cellular source of TNF are activated macrophages, but also lymphoid cells, NK cells, neutrophils, keratinocytes, fibroblasts and smooth muscle cells produce the cytokine in response to various challenges (reviewed in [31-34]). Though the first interest in TNF arose from its antitumor activity, it soon became clear that TNF has a wide range of other biological effects and is a mediator of endotoxic shock. An important cellular target of TNF is the endothelium where it induces the release of platelet-activating factor, the secretion of various cytokines and the expression of adhesion molecules. These responses, together with the activation of arachidonic acid metabolism, commonly result in increased vascular permeability, anticoagulant activity and leukocyte adhesion. Because TNF receptors are ubiquitously expressed with the exception of erythrocytes, it is not suprising that almost all cell types respond to TNF. In neutrophils, TNF activates respiratory burst and degranulation leading to the release of radicals, proteases and other granular enzymes. Macrophages respond to TNF with enhanced cytotoxic activity and cytokine synthesis. In hepatocytes TNF is, together with IL-1 and IL-6, a mediator of the synthesis of acute-phase proteins. In addition, a multitude of other effects have been described for several cell types (reviewed in [31-34]). Many of the proinflammatory activities of TNF are regulated by the transcription factor NF- $\kappa \mathrm{B}$.

Most of the biological activities of TNF including programmed cell death, antiviral activity, and activation of transcription factor NF- $\kappa \mathrm{B}$, are mediated by TNF-R1, while an involvement of TNF-R2 has been demonstrated particularly in Tlymphocytes [97-100]. Membrane-bound TNF (mTNF) and soluble TNF (sTNF) have different affinities to the two recep- tors, with TNF-R2 preferentially binding mTNF [101]. TNF-R2 appears to play an auxiliary role in cellular responses to sTNF. It has been hypothesized that TNF-R2-bound ligand may be passed over to TNF-R1 to enhance TNF-R1 signaling. This ligand passing may be favoured by the distinct kinetics of ligand association and dissociation at the two receptors. TNF binding to TNF-R2 has a fast off-rate that creates a locally high TNF concentration at the cell surface which, in turn, facilitates binding to TNF-R1 which has a slow dissociation rate [98]. The prime physiological activator of TNF-R2 seems to be mTNF, since TNF-R 2 can be more strongly stimulated by mTNF rather than by sTNF. As mTNF also signals via TNF-R1, the cooperativity of both receptors leads to responses much stronger than those achievable with sTNF alone. Moreover, it was shown that, upon appropriate activation of TNF-R2, a switch of the cellular response pattern to TNF can occur, such that cells resistant to sTNF become susceptible upon contact with mTNF [101].

Gene targeting and transgene approaches have been used to unravel the in vivo role of the TNF system. $\mathrm{TNF}^{(--)}$mice show an almost normal phenotype histologically, but have increased resistance towards lipopolysaccharide/galactosamine-mediated toxicity and defects in the clearance of intracellular pathogens such as Listeria and Candida, due to impaired macrophage functions [102, 103]. Apart from their deficiency in effector functions, $\mathrm{TNF}^{(-1-)}$ mice have some defects in lymphoid organogenesis, in particular in the structural organization of B cell follicles [104]. In contrast to TNF-R $1^{(-)}$mice [105], deletion of TNFR2 has no apparent influence on lymphoid organ development. TNF-R2 is critically involved in mediating pathogenicity during cerebral malaria, in lipopolysaccharide-induced leukostasis and down-regulation of TNF-R1-dependent neutrophil influx in a lung inflammation model [106]. A dominant role of TNF-R1 in mediating pathogenic activities was evident early on from models of septic shock and arthritis [107, 108]. The growing knowledge about the pathophysiological role of TNF has elicited several clinical trials in order to intervene with the deleterious effects of TNF in acute and chronic diseases.

The TRAMP and TRAIL systems. The biological functions of the new death receptors are largely unknown yet. TRAMP (TNF receptor-related apoptosis-mediating protein, DR3) is abundantly expressed in thymocytes and lymphocytes and may play a role in lymphocyte development $[2,8]$. The chromosomal localization of the TRAMP gene has been assigned to the long arm of chromosome 11 where other related receptors (CD30R, TNFR2, OX40R) have been mapped. TRAMP is both structurally and functionally related to the TNF receptors because its overexpression leads to NF- $\kappa \mathrm{B}$ activation and apoptosis. However, the putative ligand for TRAMP still remains to be identified.

The recent cloning of TRAIL and its four receptors revealed a new apoptosis system with apparently high complexity. Also TRAIL can induce both apoptosis and NF- $\kappa$ B activation. In contrast to the restricted expression of CD95L, TRAIL is more abundantly expressed in several tissues. Two of the TRAIL receptors, TRAIL-R1 and TRAIL-R2, induce apoptosis in various cancer cells, whereas the decoy receptors DcR1 and DcR2, which are apparently mainly expressed on normal cells, do not contain a functional death domain and confer resistance against TRAIL action [12-22]. Whether TRAIL might be used to kill more selectively tumor cells, awaits further experiments. At the moment, it is unclear why there are two death-signaling TRAIL receptors. It is possible that either the two receptors are redundant or provide additional means to regulate apoptosis. Only limited information exists on target cells of TRAIL-induced apoptosis. It was reported that TRAIL can trigger activation- 
induced death of T-cells $[10,109]$ which may also contribute to T-lymphocyte death during HIV infection [110, 111].

\section{Death receptor-associating proteins}

A major progress in the understanding of death receptor signaling was the definition of the so-called death domain (DD), an intracellular region of about 80 amino acids that is essential for triggering cell death. Its importance is demonstrated by $l p r^{c g}$ mice which carry a point mutation in the DD of CD95. Delineation of the DD was not only a major aid for the identification of new death receptors in database searches but also allowed for the identification of new adaptor molecules when used as a bait in interactive cloning approaches. The DD exerts its effects via interactive properties, as it can self-associate and bind to the DD of other proteins. These associations between DDs occur as a consequence of receptor-ligand binding and seem to involve electrostatic interactions. As assessed by NMR spectroscopy, the DD of CD95 comprises a series of antiparallel amphipathic $\alpha$-helices with many exposed charged residues [112], although it should be noted that this structure was determined at acidic $\mathrm{pH}$. The tendency of the DD to self-associate apparently strengthens the interactions of the receptors imposed by ligand binding. Following self-association, the DD of the receptors recruits other DD-containing proteins which then serve as adaptors in the signaling cascades (Fig. 2).

The first DD-containing adaptor proteins identified were FADD (MORT1) [113, 114], RIP [115] and TRADD [116]. TRADD is most effectively bound following ligation of TNF$\mathrm{R} 1$, where it then probably serves to recruit the DD proteins FADD and RIP as well as the RING domain adaptor protein TRAF2. FADD, in contrast, is preferentially recruited to CD95. Thus, the DD of FADD can bind to the DD of TRADD and the DD of RIP to the DDs of both TRADD and FADD. These mutual interactions may account for a potential crosstalk of the different receptor signaling pathways.

Overexpression of most DD proteins causes cell death, indicating that these molecules are involved in apoptosis signaling. In the case of FADD, transient expression of the N-terminal region was sufficient to cause apoptosis [113]. This part of FADD was therefore termed the death effector domain (DED). In contrast, overexpression of the C-terminal DD-containing part, lacking the DED (FADD-DN), protected cells from CD95-mediated apoptosis and functioned as a dominant-negative mutant. This suggested that the N-terminus of FADD is coupled to the cytotoxic machinery. Both TRADD and RIP induce apoptosis but can also activate NF- $\kappa \mathrm{B}$, which is a typical feature of TNFinduced signaling [116-118]. Similar to FADD, the C-terminus of TRADD contains a DD enabling self-association and association with the DD of other signaling molecules including TNFR1 and FADD. TRADD, however, lacks the typical DED present in FADD.

RIP (receptor-interacting protein) contains an N-terminal kinase domain and a C-terminal DD. It was originally identified as a molecule binding to the cytoplasmic domain of CD95 in a two-hybrid system [115]. Therefore, RIP was suggested to play a role in CD95 signaling. Later studies however demonstrated that RIP does not directly bind to CD95 or TNF-R1 but is recruited through the TNF-R adaptor protein TRAF2 [119]. RIP was identified to be crucial for TNF-R1-mediated NF- $\kappa$ B activation. In a mutant cell line deficient in RIP, CD95 signaling was not affected, whereas TNF-R1-mediated NF- $\kappa$ B activation was blocked [118].

While most of the information regarding death pathways has been obtained from yeast two-hybrid assays or supra-physiological overexpression in mammalian cells, for CD95 the signaling complexes have also been identified in vivo using classical biochemical methods [120]. Treatment of cells with agonistic antiAPO-1 antibodies and subsequent co-immunoprecipitation of CD95 resulted in the identification of four cytotoxicity-dependent APO-1-associated proteins (CAP1-4) on two-dimensional gels, within seconds after receptor triggering. Together with the receptor, these proteins formed the death-inducing signaling complex (DISC). Two spots were identified as two different serine-phosphorylated species of FADD, and it was demonstrated that FADD bound to CD95 in a stimulation-dependent fashion.

Sequencing of the other immunoprecipitated proteins resulted in the identification of a downstream molecule which contained two DEDs at its $\mathrm{N}$-terminus that associate with the DED of FADD [121]. At its C-terminus it had the typical domain structure of a protease like interleukin- $1 \beta$ converting enzyme (ICE) and was therefore termed FLICE (FADD-like ICE). FLICE was also cloned by two other groups and named MACH and Mch5 [122, 123]. It belongs to cysteine proteases of the caspase family and is therefore now referred to as caspase- 8 [124]. Identification of caspase- 8 as part of the DISC connected two different levels in apoptosis pathways, the receptor with the executioner caspases. After receptor engagement, FADD and caspase- 8 are recruited to CD95 within seconds. Binding of caspase- 8 to FADD presumably causes a structural change, resulting in autoproteolytic activation of the protease. The active subunits $\mathrm{p} 10$ and $\mathrm{p} 18$ are released into the cytoplasm, whereas part of the prodomain remains bound to the DISC. Presently, it is assumed that active caspase- 8 subunits cleave various death substrates and other caspases leading to the execution of apoptosis.

Overexpression of functionally inactive FADD and caspase-8 did not only block CD95, but also inhibited TNF-R1-induced signaling $[122,125]$. This suggested that both receptors are coupled to a similar signaling complex. However, FADD does not directly bind to TNF-R1 but becomes associated upon binding of the DD-containing protein TRADD. Similarly to TNF-R1, TRAMP can induce apoptosis and activate NF- $\kappa \mathrm{B}[2,8,9,11]$. TRAMP has been reported to bind TRADD, TRAF2, FADD and caspase-8 [8]. Due to its TNF-R1-like structure it is expected to have a signaling function analogous to TNF-R1. However, the TRAMP ligand has not been cloned, nor have agonistic antibodies been generated. All information regarding TRAMP is based on overexpression systems.

TRAIL binds to two apoptosis signaling receptors, TRAILR1 and TRAIL-R2. As with the other death receptors, TRAIL induced-apoptosis involves caspases, because caspase inhibitors as well as overexpression of CrmA and p35 abrogates cell death $[12,14,17,18,111,126]$. In fact, it was recently found that TRAIL can activate caspase- 8 . However, in contrast to CD95 which strongly activates caspase-8, TRAIL more preferentially activates caspase-10 (FLICE-2), which has a structure similar to caspase-8 [12]. A number of reports indicate that the proximal signaling pathway of the TRAIL receptors is similar but distinct from CD95. For instance, Ag8 myeloma cells are sensitive to TRAIL-induced, but not CD95L-mediated apoptosis, although CD95 is expressed in these cells [126]. In addition, it was demonstrated that HeLa cells transfected with dominant-negative FADD became resistant to CD95 but remained sensitive to TRAIL [10]. Whether apoptosis triggered by the two TRAIL receptors is FADD-dependent, remains controversial. It was initially suggested that neither TRAIL-R1 nor TRAIL-R2 signaling require FADD interaction [13, 14, 16]. More detailed reports, however, showed that overexpression of dominant-negative FADD strongly attenuated apoptosis triggered by both TRAIL receptors $[15,17,18,127]$. Thus, whether FADD is directly or indirectly coupled to TRAIL-R2 signaling requires further investigation. 


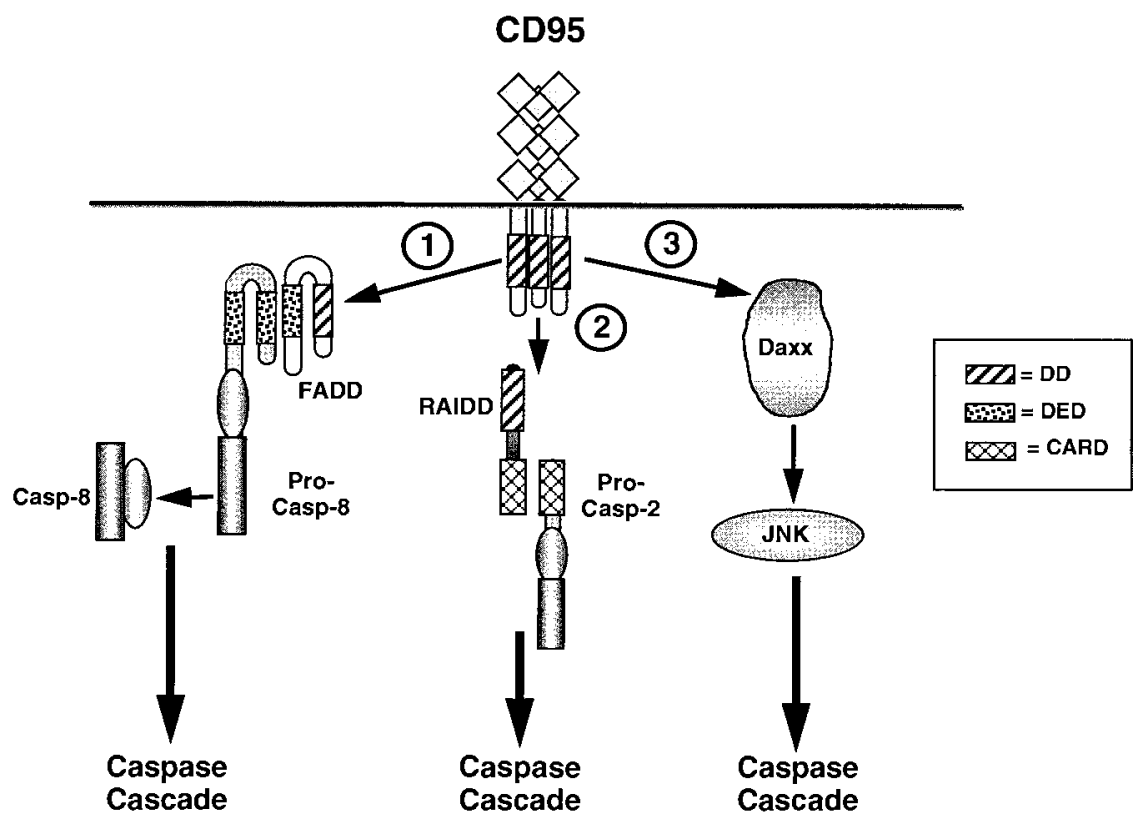

Fig. 2. Proposed pathways of CD95 proximal signal transduction. One important apoptotic pathway includes the recruitment of the adaptor protein FADD through interaction between the death domains (DD) of FADD and CD95. The death effector domain (DED) of FADD in turn recruits procaspase- 8 which is cleaved and activated at the DISC. An alternative pathway may involve activation of caspase-2 through the RIP-interacting protein RAIDD. RAIDD contains a DD and a caspase recruitment domain (CARD) that is also present in procaspase-2. A third pathway may include recruitment of Daxx to the cytoplasmic domain of CD95. This pathway involves JNK activation and further downstream activation of caspases. It should be mentioned that the physiological relevance of the latter two pathways is rather unknown.

Another possible route for death receptor signaling was recently suggested by the discovery of a new death adaptor protein, called RAIDD or CRADD (Fig. 2) [128, 129]. It was demonstrated that RAIDD can bind to TNF-R1 in vitro or when overexpressed in 293 cells. RAIDD carries the DD at its Cterminus and at its $\mathrm{N}$-terminus it displays similarities with the prodomain of caspase-2. It was therefore suggested that RAIDD would engage TNF-R1 via RIP and induce caspase-2 activation. However, the contribution of this pathway to TNF and CD95 cytotoxicity in vivo is still unknown.

It was further demonstrated that death receptors can directly trigger signaling pathways other than caspases. MADD (mitogen-activated kinase activating death domain protein) was cloned as DD-containing protein that binds to TNF-R1 and activates the MAP kinase ERK2 in a non-apoptotic pathway [130]. For CD95, a protein called Daxx was identified that specifically associates with the DD of CD95 [131]. Overexpression of Daxx stimulates stress-activated protein kinases of the MAP kinase family (JNK/SAPK) and enhances apoptosis (Fig. 2). Thus, a single receptor is able to trigger multiple pathways which, in addition, can participate in induction of cell death. Despite the key role of the $\mathrm{DD}$, the possibility that proteins associated with other intracellular regions of the receptors contribute to the overall pattern of apoptosis cannot be excluded. As will be described below, there is some evidence for such proteins, which either utilize other signaling mechanisms or which may modify a death signal elicited at the DD.

\section{Executioner caspases}

Caspases certainly constitute the key effector molecules that are required for presumably most apoptotic pathways. They are cysteine proteases which cleave their substrates after a P1 Asp residue. All caspases are synthesized as zymogens that need to be activated by proteolytic cleavage. The active enzyme is composed of a heterotetrameric complex of two large subunits of about $20 \mathrm{kDa}$ containing the active center, and two small subunits of about $10 \mathrm{kDa}$. A detailed survey on the biochemistry of caspases has recently been provided in excellent reviews [132, 133]. The following section briefly summarizes the involvement of individual caspases in death-receptor-mediated apoptosis.

First evidence for the involvement of caspases in CD95-mediated apoptosis came from pharmacological experiments that employed selective caspase inhibitors. YVAD and DEVD chloromethylketones or aldehydes that mimic the P1 Asp residue of caspase substrates, strongly suppressed CD95 and TNF-R1mediated killing [134-136]. Also the poxvirus CrmA protein, designated for cytokine response modifier A, which encodes an inhibitor of a number of caspases efficiently abrogated CD95mediated apoptosis following overexpression in a variety of cell types [134-137]. Enzymatic measurements revealed that CD95 readily induced caspase proteolytic activity within minutes after receptor ligation [135].

The importance of caspases has been first demonstrated by genetic studies in the nematode Caenorhabditis elegans in which developmental cell death is regulated by the proapoptotic regulators Ced-3 and Ced-4, and the apoptosis inhibitor Ced-9. Ced-3 has been found to exhibit significant similarity to the mammalian protease interleukin- $1 \beta$-converting enzyme (ICE) that is required for the proteolytic processing of the IL- $1 \beta$ precursor to the active cytokine [138]. In contrast to $C$. elegans, so far more than ten mammalian members of the caspase family have been identified (reviewed in [132, 133]). Based on phylogenetic analysis, they can be divided into three families. The ICE-like protease family includes ICE (caspase-1), TX/ICH-2/ICE $\mathrm{Iel}_{\mathrm{rel}} \mathrm{II}$ (caspase-4), TY/ICE $\mathrm{rel}_{\mathrm{rel}} \mathrm{II}$ (caspase-5) and ICH-3 (caspase-11) which is presumably the murine equivalent to human caspase-4. The CED-3 family includes CPP32/YAMA/apopain (caspase-3), Mch2 (caspase-6), Mch3/ICE-LAP3 (caspase-7), FLICE/ MACH/Mch5 (caspase-8), Mch6/ICE-LAP6 (caspase-9), and Mch4/FLICE2 (caspase-10). The third subfamily consists of only Nedd2/ICH-1 (caspase-2). 
Based on their structure and order of action in the death pathway, caspases can be divided into initiators and executioners. It is known that, at least for CD95-mediated apoptosis, signaling is transmitted by sequential caspase activation. However, the exact cascade of caspase activation during execution of the death pathways is still obscure. A direct link between death receptor triggering and caspase activation was established by cloning of caspase- 8 as part of the CD95 DISC [121]. The proform of caspase- 8 is recruited to the multimerized receptor and then likely activated by autoproteolytic cleavage [139]. Thus, caspase- 8 is the most upstream caspase in the CD95 pathway. As discussed previously, either caspase-8 itself or a caspase-8-like protease, such as caspase-10, is involved in a similar fashion in the signal transduction of the other death receptors. It is assumed that an apical initiator caspase cleaves and activates downstream executioner caspases, though it is unknown how many caspases are needed for the final demise of the cell. Caspase- 8 has been shown to directly cleave caspase- $3,-4,-7,-9$ and -10 in vitro, while caspase- 2 and -6 were cleaved indirectly by other caspase8 -activated caspases present in cellular extracts [140]. The order of other caspases in this cascade is not clear so far. Caspase- 6 has been placed upstream of caspase-3 and -7 [141], but it has also been demonstrated that caspase- 3 can cleave and activate caspase- $6,-7$ and $-9[123,142,143]$. A recent study further suggested a branched protease cascade in which caspase- 8 activates caspase- 3 and -7 , and caspase- 3 , in turn, activates caspase- 6 [144].

The reason for such a great variability of mammalian caspases, in comparison to C. elegans, is unclear. There is no report demonstrating that a single caspase is crucial for apoptosis signaling by death receptors. The most intensively studied caspase member is caspase-3, which is activated by multiple apoptotic signals. Depletion of caspase-3 by homologous recombination results in excessive accumulation of neuronal cells, due to a lack of apoptosis in the brain, whereas it has no effect in other tissues. This indicates that caspase- 3 may be redundant in many cell types [145]. The role of caspase- 1 in apoptosis is also controversial. It has been suggested that caspase- 1 is involved in CD95-mediated apoptosis of thymocytes, in apoptosis of mammary cells following matrix loss, and in lymphocyte apoptosis dependent on DNA damage-induced interferon regulatory factor-1 (IRF-1) [146-148]. However, others could not find an impairment of apoptosis in caspase- $1^{(-)-}$mice $[149,150]$. Therefore, either caspase- 1 does not play a role in death receptor signaling, or another caspase-1-like protease substitutes for its function in different contexts.

An increasing number of proteins have been found to be cleaved by caspases, and for some of them an apoptotic function could be attributed (reviewed in [132, 133]). Sometimes cleavage results in the activation of a protein or enzyme, sometimes in its inactivation. Substrates include proteins involved in genome function, such as the DNA repair enzyme poly(ADP-ribose) polymerase (PARP), DNA-polymerase kinase, 70-kDa U1, heteronuclear ribonucleoproteins C, and the $140-\mathrm{kDa}$ component of the DNA replication complex. Regulators of the cell-cycle progression which are cleaved are the retinoblastoma protein, the 53 regulator MDM-2, the nuclear mitotic-associated protein NuMA and the kinases PKC- $\delta$, PITSLRE and MEKK1. The cleavage of lamins, which is dependent on caspase-6, may be essential for disassembling the nuclear architecture. Important caspase substrates include structural proteins such as Gas2, gelsolin, $\beta$-catenin, keratin 18 and fodrin. Cleavage of these proteins may be responsible for the complete reorganization of the cellular morphology during apoptosis.

One of the first death substrates found to be cleaved by caspases, particularly caspase- 3 and -7 , was PARP. The enzyme catalyzes the transfer of ADP-ribose moieties to nuclear proteins which may result in protein modification and $\mathrm{NAD}^{+}$depletion. As DNA strand breaks activate the enzyme, PARP has been proposed to trigger DNA-damage-induced apoptosis by depleting NAD stores. On the other hand, due to its DNA repair activity, PARP may exert a protective function. It has been proposed that, during CD95-induced apoptosis, cleavage of PARP inhibits most of its DNA repair activity, and thus may contribute to the demise of the cell [151]. To analyze whether PARP cleavage is critical for cell death, we have recently investigated CD95 and TNF$\mathrm{R} 1-$ mediated apoptosis in PARP ${ }^{(-)-}$mice. In a variety of tissues, no difference in apoptosis sensitivity of $\mathrm{PARP}^{(-)}$and parental mice was detected [152]. Therefore, although PARP ${ }^{(-l-)}$ mice have defects in genomic stability, cleavage of PARP is dispensable for death receptor signal transduction.

An interesting substrate of caspases is the upstream p21-activated kinase-2, PAK2, which is cleaved during CD95- and TNFmediated apoptosis to generate a constitutively active kinase [153]. Since PAK2 activates the stress-activated protein kinase (SAPK) pathway, it may provide the link between caspases and JNK/SAPK activation. Interestingly, blocking PAK2 by a dominant-negative mutant prevents the formation of apoptotic bodies during CD95-mediated apoptosis, whereas nuclear apoptosis as well as phosphatidylserine externalization remain unaffected [153]. This illustrates how different features of apoptosis might be separated at the level of caspase targets.

A direct link between caspases and DNA fragmentation was recently found by the cloning of a hitherto unknown murine endonuclease, designated CAD for caspase-activated DNase [154]. CAD is sequestered in the cytosol as a latent form by binding to the inhibitory subunit ICAD. Upon induction of apoptosis, ICAD is cleaved by caspase-3, which allows the DNase to translocate to the nucleus and to degrade DNA. The structure of ICAD is similar to human DNA fragmenting factor (DFF) which has previously been reported to be cleaved by caspase-3 and to permit endonuclease activation [155]. It is interesting to note that overexpression of ICAD/DFF blocks chromatin changes of apoptosis, but does not abrogate other morphological alterations.

Despite compelling evidence for a key role of FADD-mediated recruitment of caspase- 8 to CD95 and TNF-R1, it should be stressed that the precise scenario of receptor-mediated caspase activation is still fragmentary and most experiments have only been performed in a limited number of cell lines. Besides the FADD/caspase- 8 pathway, a novel pathway has been identified which is controlled by Apaf-1 (apoptotic protease-activating factor-1), the mammalian homologue of the C. elegans death regulator Ced-4 [156] (Fig. 3). It is still unclear whether the Apaf-1/Ced-4 pathway functions completely independently or is interconnected with the caspase- 8 pathway. In C. elegans, Ced-4 physically interacts with both the Bcl-2 homologue Ced-9 and the caspase Ced-3, thus linking the upstream inhibitor and the downstream effector to a multicomponent death complex [157, 158]. In addition, direct binding between Ced-4 and mammalian caspase- 1 and caspase- 8 has been observed. Human Apaf-1 possesses three distinct domains suggesting that its regulation is more complex than that of worm Ced-4. The C-terminal part of Apaf-1 is composed of putative WD40 repeats, followed by a stretch of amino acids similar to Ced-4. The $\mathrm{N}$-terminal region of Apaf-1 shares sequence similarity with the N-terminal domain of Ced-3 and some other mammalian caspases. This domain serves as a so-called caspase recruitment domain (CARD) by binding to caspases that have a similar CARD motif at their Nterminus [159]. In particular, caspase- 9 is recruited to Apaf-1 [160]. In cells not undergoing apoptosis, the CARD is not exposed and therefore not bound to procaspase-9. However, bind- 


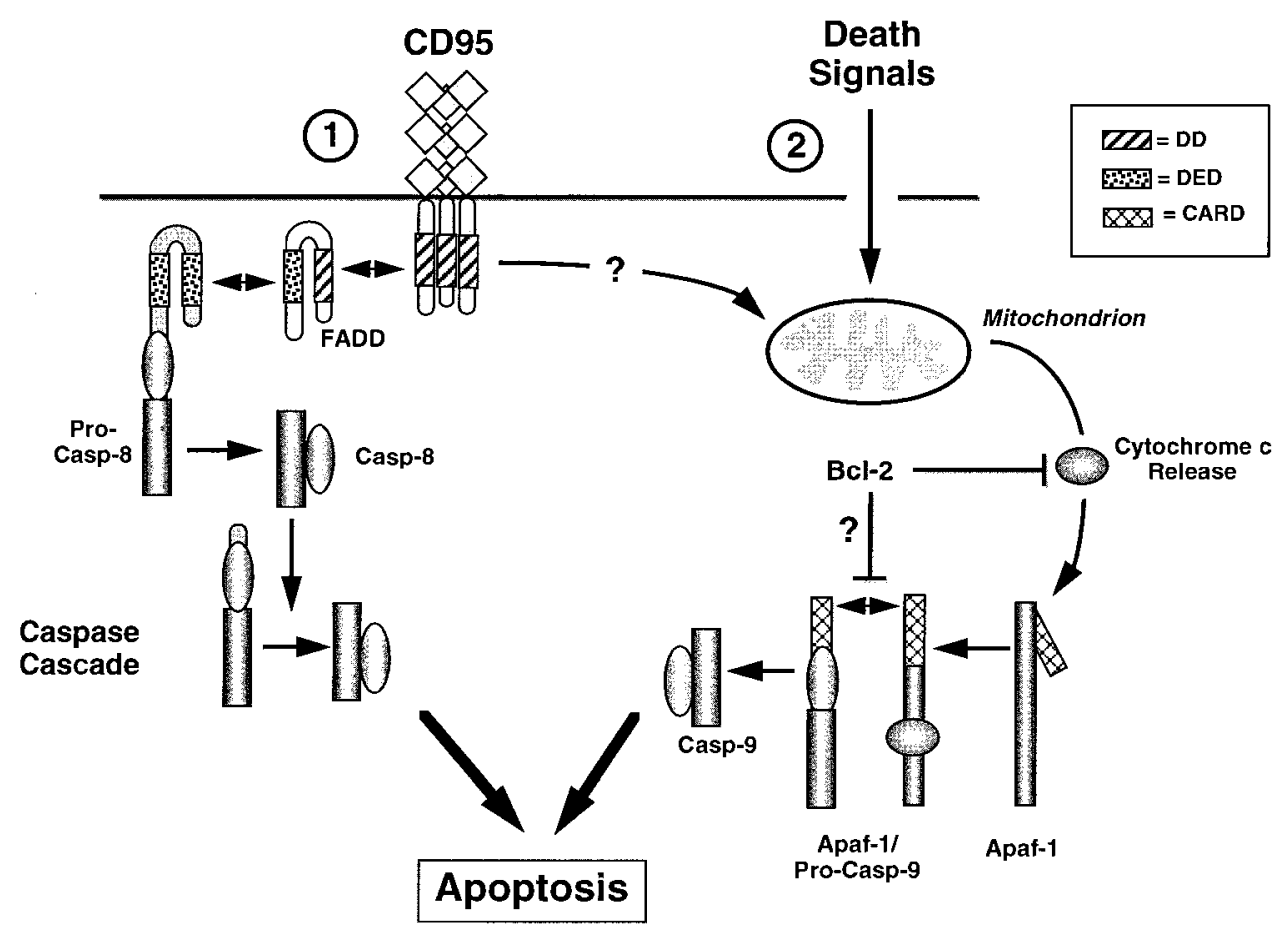

Fig. 3. Two principal pathways of apoptosis signal transduction. One death pathway involves FADD-mediated recruitment of caspase- 8 to the CD95 receptor complex. Another pathway, which is triggered by many apoptotic stimuli, is initiated at the mitochondrion. An early, not wellunderstood, step is the release of cytochrome $c$ into the cytosol which then binds to the Ced-4 homologue Apaf- 1 . This event unmasked the CARD motif in Apaf-1 and allows binding of pro-caspase-9 through homophilic interaction. The mitochondrial pathway but not FADD-mediated caspase-8 activation is inhibited by Bcl-2. Anti-apoptotic members of the Bcl-2 family may interfere with the relocalization of cytochrome $c$ or with the binding of cytochrome $c$ to Apaf-1. Because cytochrome $c$ release is also found following death receptor ligation, both pathways may be interconnected at an unknown level.

ing of ATP and cytochrome $c$, that is released from mitochondria during early cell death [161], presumably induces a conformational change and unmasks the CARD in Apaf-1 (Fig. 3). This event finally culminates in the recruitment and activation of caspase-9. Similarly to caspase- 9 , caspase- 1 and caspase- 2 also contain a CARD region. Thus, it is possible that these initiator caspases are recruited to Apaf-1 and may act independently of FADD and other adaptor proteins. Since relocalization of cytochrome $c$ is observed during TNF-R1- and CD95-mediated apoptosis, the Apaf-1-controlled pathway may also be functional in these systems. However, the link between death receptors, Apaf-1 and mitochondrial alterations remains to be established.

There are some hints that other classes of proteases are also important and contribute to the execution of cell death. In a cloning approach to isolate positive regulators of apoptosis, cathepsin D, a lysosomal cysteine protease, was found to play a role in cell death mediated by IFN $\gamma$, TNF and CD95 [162]. In HeLa cells, cell death was inhibited following overexpression of an antisense cathepsin D construct or inactivation of the protease with the inhibitor pepstatin A. Furthermore, in TNF cytotoxicity in particular serine proteases have been implicated [163, 164]. It was demonstrated that overexpression of plasminogen activator inhibitor-2 (PAI-2) prevented apoptosis in HT-180 and HeLa cells $[165,166]$. In U937 cells, a 24-kDa elastase-like serine protease, called AP24, has been purified that is rapidly activated during TNF-induced apoptosis $[167,168]$. There are some inhibitors of AP24 activation that do not affect caspase-3 but fully prevent DNA fragmentation and apoptosis. Interestingly, in TNF-sensitive L929 cells overexpressing CD95, certain inhibitors of serine proteases abolish TNF-mediated but not CD95mediated cell death [169]. As will be described below, these observations indicate that, in some cell types, distinct effector molecules may participate in both receptor pathways.

\section{The sphingomyelin pathway}

Another apoptotic pathway implicated in death receptor-mediated apoptosis involves the generation of ceramide by the hydrolysis of the phospholipid sphingomyelin. Ceramide is a second messenger produced upon activation of sphingomyelinases (SMases) or via de novo synthesis by ceramide synthetase. Two forms of SMases can be distinguished based on their $\mathrm{pH}$ optima. Neutral SMase has a $\mathrm{pH}$ optimum of 7.4 , requires $\mathrm{Mg}^{2+}$ ions and is found at the plasma membrane. Acidic SMase has the highest enzymatic activity at $\mathrm{pH} 5.0$, is activated by diacylglycerol and mainly present in lysosomes. A multitude of non-apoptotic and apoptotic stimuli can activate sphingomyelin turnover including ionizing irradiation, oxidative stress, treatment with doxorubicin or ligation of TNF-R1 and CD95 [170-174]. Ceramide generated as a result of sphingomyelin turnover, in turn, can stimulate various target molecules, such as ceramideactivated protein kinase (CAP kinase), ceramide-activated protein phosphatase (identical to PP2A), the protein kinase C isoform $\zeta$, and Raf-1. A specific role for ceramide in mediating apoptotic signals was suggested by the apoptotic effect of exogenous short-chain ceramides or the treatment of cells with bacterial SMase.

TNF-R1 has been shown to activate neutral SMase through FAN (factor-associated neutral SMase), a protein that interacts with a stretch of nine amino acids upstream of the DD. A dominant-negative mutant of FAN is able to block TNF-R1-mediated neutral SMase activation completely without affecting cell death [175]. Similarly to TNF-R1, mutant CD95, which is defective in death signaling, is still able to activate neutral-SMase [172]. Therefore, neutral SMase-mediated ceramide production is presumably independent of cell death signaling by CD95 and TNF-R1. 
Ceramide production by acidic SMase is mediated through the prior activation of the phosphatidylcholine-specific phospholipase C (PtdCho-PLC). The region of TNF-R1 which initiates the PtdCho-PLC/acidic SMase pathway corresponds to the DD of TNF-R1. The xanthogenate compound D609 inhibits this pathway and is able to prevent TNF-induced cell death in various cell types [176]. However, it has been found that cells from patients with Niemann-Pick disease type A, which lack functional acidic SMase, are resistant to ionizing irradiation, but not to CD95- or TNF-R1-induced apoptosis [177]. Therefore, although both neutral and acidic SMase have been implicated in ceramide production and death signaling through CD95 and TNF-R1, neither of them seems to be essential or sufficient for apoptosis induction by these receptors.

Another metabolizing pathway for ceramide was proposed by Testi and coworkers [178]. Ceramide can be shuttled to the Golgi complex where it is converted to gangliosides. It was found that CD95 ligation or treatment with ceramide resulted in the accumulation of the ganglioside GD3, an event, which was inhibited by caspase inhibitors. Antisense oligonucleotides to GD3 synthetase, which is localized in the Golgi complex, attenuated apoptosis, whereas overexpression of wild-type enzyme was associated with massive cell death. It was suggested that, during CD95-mediated apoptosis, GD3 ganglioside may be targeted to mitochondria where it alters mitochondrial function and causes cell death.

It should be stressed that there is currently much confusion about the role of endogenous ceramide in apoptosis. Whereas some publications place ceramide production upstream of caspases $[179,180]$, others suggest that it acts downstream of caspases, as it can be blocked by caspase inhibitors [92, 181, 182]. Moreover, ceramide production may be not necessarily linked to apoptosis, as it is also observed after $\mathrm{Ca}^{2+}$ ionophore treatment without being associated with cell death [182]. A possible reason for the discrepancy on the role of ceramides may lie in methodological problems. Ceramide production is mostly determined in assays using diacylglycerol kinase. In a recent investigation, no ceramide production in response to CD95 ligation could be detected using mass spectroscopy, whereas an apparent increase of ceramide was measured by the classical diacylglycerol kinase assay [183]. It was suggested that lysates from apoptotic cells may stimulate diacylglycerol kinase activity directly, which then falsely reflects increased ceramide production. Thus, whether sphingomyelin hydrolysis is functionally involved in the propagation of death signals or represents a secondary modulatory pathway has to await careful reexamination.

\section{Stress-activated protein kinases}

There is evidence linking apoptosis induced by CD95 and TNF-R1 to the activation of two MAP kinase homologs, called the stress-activated protein kinases (SAPKs), also known as c-Jun N-terminal kinase (JNK), and the kinase p38. CD95 and TNF-R1 are able to increase the activity of these kinases although, compared to most stress stimuli activation, CD95-induced activation is rather slow but sustained. It is still unclear whether kinase activation contributes to apoptosis or constitutes an independent pathway of death receptor signaling.

When the relationship between SAPK/JNK and apoptosis in response to TNF-R1 ligation was analyzed, it was found that the adaptor protein TRAF2 was involved in SAPK/JNK activation but not in apoptosis. Furthermore, a dominant-negative FADD inhibited apoptosis but not kinase activation [184, 185]. Thus, dominant-negative TRAF2 and FADD mutants clearly dissociate SAPK/JNK activation from induction of apoptosis. In addition, activation of $\mathrm{p} 38$ by TNF is not involved in cell death [186], suggesting that the cytotoxic signal of TNF-R1, and the activation of SAPK/JNK and p38, are two signaling pathways separated at the receptor level. CD95 can activate SAPK/JNK and p38, although TRAF2 is not associated with this receptor [187, 188]. SAPK/JNK activation has been located downstream of caspases in the CD95 pathway, since it can be blocked by the caspase inhibitors. SEK1, an upstream activator kinase of SAPK/JNK, is able to inhibit SAPK/JNK activation when expressed as a dominant-negative mutant without affecting CD95mediated apoptosis [189]. This suggests that the pathway of SAPK/JNK activation is independent from apoptosis induction.

At present, however, there are also data suggesting that MAP kinases may play either a positive or a negative role in the regulation of apoptosis. A recent study identified a novel upstream activator of the MAP kinase pathway, termed ASK-1 (apoptosis signaling kinase-1) [190]. The enzyme is assumed to contribute to TNF-mediated cytotoxicity, because a kinase-dead ASK-1 mutant inhibited TNF-induced apoptosis. Some studies further revealed that certain upstream elements of the different MAP kinase cascades are targeted and cleaved by caspases. As mentioned above, PAK2 which is regulated by p21-GTPases, is cleaved during CD95 and TNF-mediated apoptosis, leading to a constitutively active kinase. Overexpression of the active Cterminal part of PAK2, which is generated during caspase action, induces apoptosis. Interestingly, a dominant-negative PAK2 inhibited the formation of apoptotic bodies, whereas other signs of apoptosis remained unaffected [153]. In addition, MAP kinase kinase-6b (MKK6b), an upstream mediator of p38 and SAPK/ JNK activation, is activated in a caspase-dependent manner and is apparently necessary for CD95-mediated apoptosis in Jurkat cells [191]. Finally, a direct link between death receptor signaling and activation of the SAPK/JNK pathway was identified through the cloning of Daxx, a protein that interacts with the DD of CD95 and leads to caspase-independent SAPK/JNK activation. It was demonstrated that a dominant-negative SEK1 mutant was able to block both SAPK/JNK activation and cell death in certain cells [131]. In contrast, thymocytes deficient in SEK1 were found to be more sensitive towards CD95 and anti-CD3induced apoptosis, whereas apoptosis induced by other environmental stresses was unaffected [192]. Therefore, a secondary apoptotic pathway may exist in certain cells which is dependent on activation of MAP kinases and may either cooperate with or antagonize the caspase cascade. Clearly, delineation of its biological relevance requires further investigation.

\section{Reactive oxygen intermediates}

Cells die by one of the two mechanisms, necrosis or apoptosis. While triggering of a death receptor will lead to apoptosis in most cells, there are some conditions where death receptors clearly trigger necrotic cell death. Necrosis is often referred to as accidental cell death and is induced when the plasma membrane of a cell is irreversibly damaged. Biochemically, these alterations seem to be less regulated than apoptosis, and a number of pathways have been implicated in necrosis, including generation of reactive oxygen intermediates, activation of phospholipases, perturbation of calcium homeostasis, and unspecific DNA and protein damage (reviewed in [193, 194]).

In both necrosis and apoptosis, mitochondria obviously play a critical role, as in both forms of cell death a rapid and dramatic decrease in the mitochondrial membrane potential $\left(\Delta \Psi_{\mathrm{m}}\right)$ is observed $[195,196]$. The drop in $\Delta \Psi_{\mathrm{m}}$ is due to permeability transition and allows molecules to be released from the mitochondrial matrix. In cells treated with apoptogenic agents, antiapoptotic members of the Bcl-2 family that are localized at the outer mitochondrial membrane prevent permeability transition 
and the release of cytochrome $c$. During necrotic cell death, membrane permeability transition may lead to increased radical production, which in turn will cause cell damage through the oxidation of lipids, proteins and other components. This common occurrence of mitochondrial alterations, such as permeability transition, in necrosis and apoptosis indicates that some signaling processes might be shared between the two forms of cell death. Although it is not entirely clear which event decides whether a cell undergoes apoptosis or necrosis, the supply with ATP and other energy equivalents are likely determinants of this process [197].

Among the death ligands, TNF at least has been reported to be able to induce apoptosis and necrosis [198]. A necrotic cell death is exemplified, for instance, by TNF-treated L929 fibroblasts, which are often used as the prototype of TNF-sensitive cells. There is ample evidence that during TNF-induced necrosis mitochondria-derived ROIs are the critical mediators of cell death. Already early studies showed that TNF treatment caused ultrastructural abnormalities of mitochondria, as they appeared swollen and contained fewer cristae [199, 200]. Furthermore, when cells were treated with certain antioxidants or kept under anaerobic conditions TNF cytotoxicity was strongly reduced [200]. Pharmacological experiments revealed that the mitochondrial respiratory chain was the major source of TNF-induced formation of reactive oxygen intermediates [200, 201]. It was also observed that cell clones, which had been selected for the depletion of mitochondrial DNA (mt-DNA) and therefore lacked mitochondrial respiration, were almost completely resistant to TNF-induced cytotoxicity [201]. Hence, the evidence suggests that reactive oxygen intermediates generated in the mitochondrial electron transport chain play an important role for TNF-induced necrosis.

Interestingly, cells that are devoid of mtDNA and a functional respiratory chain can still undergo apoptosis, for instance induced by staurosporine treatment or CD95 ligation [202]. This can be explained by the fact that mtDNA-deficient cells still maintain a mitochondrial membrane potential and may release cytochrome $c$ or other factors that can engage the apoptotic machinery. Thus, although in some cells TNF-R1- and CD95-mediated cell death appears to involve similar signaling pathways, there are also examples demonstrating that death induction by the two death receptors must be distinct. Differences between TNF-R1 and CD95 signaling can be even evident within the same cell. L929 cells overexpressing CD95 exhibit typical alterations of apoptosis when stimulated with anti-CD95, such as membrane blebbing, cytoplasmic shrinkage and internucleosomal DNA fragmentation. In contrast, in the same cells, TNF induces necrosis as evident by changes in the mitochondrial ultrastructure and lack of nuclear apoptotic alterations [83, 169]. Differences between the two receptors are also observed with pharmacological inhibitors. While mitochondrial inhibitors or antioxidants almost completely block TNF-R1-mediated cell death, they do not affect CD95-mediated cytotoxicity [83, 203]. These different effects may be related to the distinct morphological forms of cell death that are induced upon CD95 and TNF$\mathrm{R} 1$ in certain cell types.

There are other differences between TNF-R1 and CD95-mediated signal transduction. As described above, TNF is a potent inducer of the transcription factor NF- $\kappa \mathrm{B}$ and pro-inflammatory gene expression, whereas the biological function of CD95 is largely restricted to apoptosis. As reactive oxygen intermediates have been proposed as second messengers of NF- $\kappa \mathrm{B}$ activation (reviewed in [204]), the lack of NF- $\kappa$ B activation by CD95 may concur with the notion that CD95 signal transduction is independent of reactive oxygen intermediates. Another difference is the time course of killing induced by both death receptors. CD95 triggers death very rapidly, while in most cell lines TNF-R1mediated cell death proceeds more slowly. The reasons for the different kinetics are unknown, but they are inconsistent with the idea of similar death-inducing complexes of the two receptors. It has been further observed that a number of cell lines are only sensitive to either CD95 or TNF-R1, although both receptors are expressed in similar amounts [205, 206].

\section{Cellular anti-apoptotic mechanisms}

Whether triggering of a death pathway results in apoptosis depends, not only on the expression level of a death effector molecules, but also on resistance mechanisms that counteract an apoptogenic signal. Apoptosis is often enhanced by inhibitors of protein synthesis, indicating that cells produce short-lived antiapoptotic proteins. Since apoptosis serves as an important defense mechanism to combat viral infections, viruses have developed their own or adopted the host's machinery to suppress apoptosis. The identification of viral anti-apoptotic genes led in many cases to the discovery of their cellular homologues that act to prevent cell death. In the following, we will describe various mechanisms that interfere with cell death at very distinct steps in the signal transduction pathway of death receptors.

Receptor-associated mechanisms. The most proximal step to suppress a death receptor pathway is the inhibition of ligand binding. Members of the death receptor family can sometimes be found as truncated forms of the extracellular domain, which are either derived from alternative gene splicing or from proteolytic shedding. It has been proposed that expression of the soluble extracellular part of CD95 is elevated and may account for the defective apoptosis in systemic lupus erythematosus (SLE) [207], though this finding could not be confirmed by other investigators [208, 209]. An interesting mechanism of neutralizing a death ligand is found in the TRAIL system. The membrane expression of the decoy receptors DcR1 and DcR2, which binds TRAIL without signaling for cell death, is held responsible for the resistance of normal cells to TRAIL cytotoxicity $[13,14,16$, 19-21].

A further downstream level at which apoptosis can be prevented is the signaling activity of a death receptor. A negative regulatory role has been suggested for the C-terminus of CD95, since deletion of its last 15 amino acids increases apoptosis sensitivity [7]. This region of CD95 has been found to interact with a protein-tyrosine phosphatase, called Fas-associated phosphatase-1 (FAP-1) [210]. Overexpression of FAP-1 partially inhibits CD95-induced apoptosis. The region that is required for interaction with FAP-1 has been narrowed down to the last three amino acids, and microinjection of this tripeptide into cells blocked FAP-1 binding and facilitated CD95 signaling [211]. Yet, so far conclusions on a negative regulatory role of FAP-1 are based mainly on correlations and only the association of FAP-1 with human but not mouse CD95 has been detected [212]. The markedly different expression pattern of FAP-1 and CD95 rather suggest that FAP-1 plays no essential role in CD95 signal transduction.

Recently, it was suggested that signal transduction of TNFR1 and CD95 may be modulated by a pathway related to ubiquitination. A novel protein with sequence similarity to ubiquitin, called sentrin, was found to bind to the DD of CD95 and TNFR1 [213]. When overexpressed, sentrin provides protection against TNF- and CD95-mediated apoptosis. Sentrin associates strongly with the ubiquitin-conjugating enzyme UBC9 [214] that was also found to be associated with CD95 [215]. It is believed that UBC9 catalyzes the conjugation of ubiquitin or sentrin to 
other molecules. Whether this process inhibits cell death by blocking binding of DD adaptor proteins remains to be shown.

FLICE-inhibitory proteins. Shortly after the discovery of caspase- 8 which contains two $\mathrm{N}$-terminal regions related to the DED of FADD, homologous viral proteins were identified that intriguingly lacked caspase activity. These proteins were called v-FLIPs (viral FLICE-inhibitory proteins) because, following overexpression in mammalian cells, they bind to the death-receptor-FADD complex but prevent caspase-8 recruitment [216218]. v-FLIPs are expressed as E8 proteins of several herpes viruses (reviewed in [219]). For v-FLIP of herpesvirus saimiri8 , it was shown that the protein is expressed in the late lytic cycle and renders cells resistant to CD95 [216]. v-FLIPs consist of two DEDs without a caspase-like catalytic domain. They can thereby act as dominant-negative proteins and compete for caspase-8 recruitment to the DISC. Consequently, overexpression of v-FLIPs results in protection against CD95-, TNF-R1, and TRAIL receptor-induced apoptosis [216-218].

Following the identification of viral FLIPs, a cellular homologue, called c-FLIP, was also cloned which presumably acts as an important death regulator in mammalian cells [220]. c-FLIP was independently identified by several groups and is also termed Casper, I-FLICE, FLAME-1, CASH, CLARP, and MRIT [221-226]. Its gene was localized to the long arm of chromosome $2 \mathrm{Ze} \mathrm{(2q33-34)}$ where the genes for caspase- 8 and caspase10 are also clustered. c-FLIP is expressed in various tissues and occurs in two splice variants. Similarly to v-FLIP, the short-form c-FLIP $_{\mathrm{S}}$ contains two N-terminal DED motifs through which it can bind to other DED proteins. The long-form FLIP $_{\mathrm{L}}$, in addition, contains a C-terminal region resembling the proteolytic domain in caspase- 8 and -10 . The most remarkable feature of c-FLIP is that the active-site Cys is absent and substituted by Tyr residue. Therefore c-FLIP can be suggested to be proteolytically inactive.

It was found that c-FLIP can associate with different proteins including FADD, caspase-8 and caspase-3. Also an independent association with the TNF-R1-bound protein TRAF2 and with $\mathrm{Bcl}-\mathrm{x}_{\mathrm{L}}$ has been noted $[221,226]$. Curiously, quite opposite effects were reported following transfection of c-FLIP cDNA into mammalian cells. By most groups, a protective effect of c-FLIP on TNF-R1, CD95, TRAMP or TRAIL-induced apoptosis was detected [220, 222, 223]. This concurs with observations made for the viral homologues that act as dominant-negative inhibitors of caspase- 8 activation. In contrast, other studies reported a marked cytotoxic effect of c-FLIP [221, 225, 226]. This proapoptotic effect could result from the ability of c-FLIP to activate caspase- 8 via homophilic interaction through its corresponding DED, which would be similar to the mechansism suggested for FADD/caspase- 8 interaction. This discrepancy in the observed effects may also be due to the cell line used or the supraphysiological range of expression in transfection experiments. Because a pro-apoptotic effect of c-FLIP was seen especially following massive overexpression of the protein, the true function of c-FLIP may be the inhibition of apoptosis. This notion is consistent with the amount of c-FLIP in T-lymphocytes. c-FLIP is strongly expressed in early activated T-cells where it was shown that caspase- 8 is not recruited to the CD95/FADD complex [227]. c-FLIP expression, however, declines later, when T-cells become susceptible to CD95.

The family of IAPs. Inhibitor of apoptosis proteins (IAPs) constitute a family of conserved molecules which were originally discovered in baculovirus. The first human IAP identified was the neuronal apoptosis inhibitory protein (NIAP) which was isolated based on its contribution to the neurodegenerative disor-
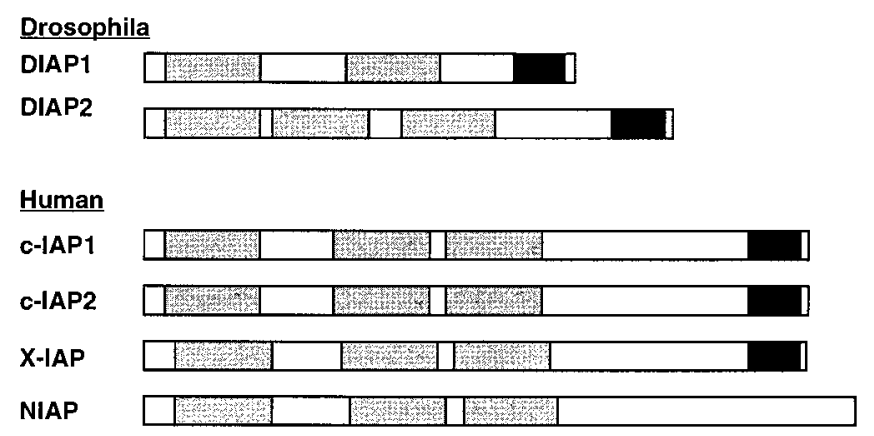

Survivin
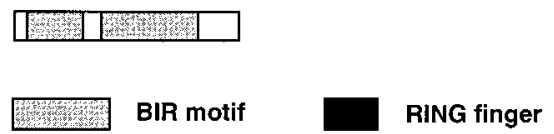

Fig.4. Schematic representation of IAP family members. The proteins were originally identified in baculovirus and are structurally similar. All members are characterized by Cys/His-rich BIR (baculovirus IAP repeat) motifs, which are essential for anti-apoptotic action. Some IAP members also contain a C-terminal RING finger motif of rather unknown function.

der spinal muscular atrophy [228]. Subsequently, four other human IAPs, called c-IAP1, c-IAP2, X-IAP and survivin, have been isolated and demonstrated to counteract cell death [105, 229-231]. c-IAP1 and c-IAP2 were identified as molecules that are recruited to the cytosolic domain of TNF-R2 via their association with TRAF1 and TRAF2 [105]. c-IAP1, in addition, has been shown to be a component of the TNF-R1 complex via its association with TRAF2 [232].

The common structural feature of all IAP family members is a Cys/His-rich motif termed the baculovirus IAP repeat (BIR) that is present in one to three copies (Fig. 4). With the exception of NIAP and survivin, all other IAP family members also contain a zinc-finger-like RING domain at their carboxy terminus. The fact that the BIR motif is shared by all members suggest a central role for this domain in mediating cellular protection. Recently, it was shown that some IAP members, including XIAP, c-IAP1 and c-IAP2, can bind to and potently inhibit certain caspases, such as caspase- 3 and -7 [233, 234]. Inhibition of these caspases was also found in vitro, whereas the activity of the proximal proteases caspase-1, -6 and -8 was not affected. Mutational analysis revealed that the BIR domains were sufficient for the inhibitory effect, though proteins that retained the RING finger domain were more efficient. In contrast to the other human IAPs, NIAP did not bind or inhibit caspases [234], suggesting that IAPs may have additional targets of apoptosis inhibition. A detailed analysis of the mechanism of inhibition revealed that IAPs bind, but are not cleaved by, the caspases [234]. This is in contrast to the poxvirus inhibitor CrmA and baculovirus protein p35 which require peptide bond hydrolysis as part of their inhibitory mechanism [235-237].

At present, the role of c-IAP1/2 recruitment to the TNF receptors is unknown. Inhibition of caspases is independent of TNF-R binding function [234], though it is possible that recruitment of IAPs to the TNF-R may promote their interaction with caspases. Alternatively, it has been also suggested that the function of c-IAP2 may be associated with the activation of NF- $\kappa \mathrm{B}$, which is known to play the role of an anti-apoptotic transcription factor (see below). Overexpression of c-IAP2 directly stimulated $\mathrm{NF}-\kappa \mathrm{B}$ activation and interfered with TNF-induced cell death [238]. This effect required the RING domain of c-IAP2 indicating that, in addition to caspase inhibition, IAPs may prevent apoptosis by alternative mechanisms. 
The Bcl-2 family of proteins. Bcl-2 proteins constitute another important decisional point of cell death. The Bcl-2 family consists of two functional classes of proteins including antiapoptotic members, such as Bcl-2, Bcl- $\mathrm{x}_{\mathrm{L}}$, Mcl-1, Bcl-w, Bfl-1, Brag-1 and A1, as well as pro-apoptotic molecules, such as Bax, Bad, Bak, Bid, Bik, Bim and Hrk (reviewed in [239, 240]). Bcl-2 members are characterized by up to four so-called Bcl-2 homology $(\mathrm{BH})$ domains, and can interact with each other through a complex network of homo- and heterodimers. Originally, it has been proposed that the ratio of pro- and anti-apoptotic members dictates whether a cell responds to a proximal apoptotic stimulus or not. Indeed, overexpression of $\mathrm{Bcl}-2 / \mathrm{Bcl}-\mathrm{x}_{\mathrm{L}}$ abrogates cell death, while enforced expression of Bax promotes apoptosis [241, 242]. Recent evidence, however, has challenged the model of heterodimerization of $\mathrm{Bcl}-2$ proteins. Selected $\mathrm{Bcl}-\mathrm{x}_{\mathrm{L}}$ mutants which fail to heterodimerize with Bax can still inhibit apoptosis [243, 244]. Vice versa, mutants of Bax and Bak which do not bind Bcl- $\mathrm{x}_{\mathrm{L}}$ still exert their pro-apoptotic activity $[245,246]$. It therefore seems that these Bcl-2 family members instead of heterodimerizing compete for a common binding partner.

Various models have been proposed to explain how Bcl-2 proteins inhibit apoptosis. It was demonstrated that after transient transfection Bcl- $\mathrm{x}_{\mathrm{L}}$ can bind to caspase- 8 , suggesting that this interaction would inhibit activation of caspase-8 [157]. In contrast, in MCF7-Fas cells, which were selected for CD95 resistance by overexpression of $\mathrm{Bcl}-\mathrm{x}_{\mathrm{L}}$, no association between caspase-8 and Bcl- $\mathrm{x}_{\mathrm{L}}$ was detected [247]. Likewise, activation of caspase-8 in response to CD95 ligation was unaffected. However, although DISC-bound caspase- 8 may not be targeted by Bcl-2, the processing of downstream caspases including caspase- 3 is prevented by $\mathrm{Bcl}-2$ or Bcl- $\mathrm{x}_{\mathrm{L}}$ in many apoptotic systems [248, 249]. Thus, Bcl-2 proteins may inhibit cell death by acting downstream of initiator but upstream of executioner caspases.

The principal site of action of $\mathrm{Bcl}-2$ is presumably the mitochondrion, as Bcl-2 seems to prevent all alterations of apoptosis that occur in this organelle (Fig. 3). Bcl-2-inhibitory proteins have been shown to prevent the formation of mitochondrial reactive oxygen intermediates, alterations in calcium homeostasis, and mitochondrial membrane permeability transition. Interesting findings also came from cell-free experiments. Bcl-2 prevents the release of an apoptogenic protease, called apoptosis-inducing factor, by isolated mitochondria [250]. Experiments in vitro demonstrated that Bcl-2 proteins can interact with Apaf- 1 and caspase- 9 and may thereby sequester this ternary complex at the outer mitochondrial membrane [251]. Various studies revealed that $\mathrm{Bcl}-2$ inhibits the release of cytochrome $c$ which otherwise, upon binding to Apaf-1, would activate the caspase cascade $[252,253]$. In addition, cytochrome $c$ could induce apoptotic alterations and caspase cleavage in vitro or when microinjected into cells [254].

The mechanisms of cytochrome $c$ release and its inhibition by Bcl-2 are unknown. An interesting hint may be provided by the three-dimensional structure of Bcl- $\mathrm{x}_{\mathrm{L}}$ which reveals a similarity to the pore-forming domains of some bacterial toxins [255]. Indeed, both Bcl-2 and Bcl- $\mathrm{x}_{\mathrm{L}}$ have been shown to form ion channels in artificial lipid bilayers [256, 257]. Different Bcl-2 family members might form channels with distinct selectivity which could regulate permeability of the outer mitochondrial membrane. It has been shown that Bcl-2 inhibits mitochondrial swelling during apoptosis that is presumably caused by a damage of the outer mitochondrial membrane [258]. This osmotic swelling precedes redistribution of cytochrome $c$ and permeability transition.

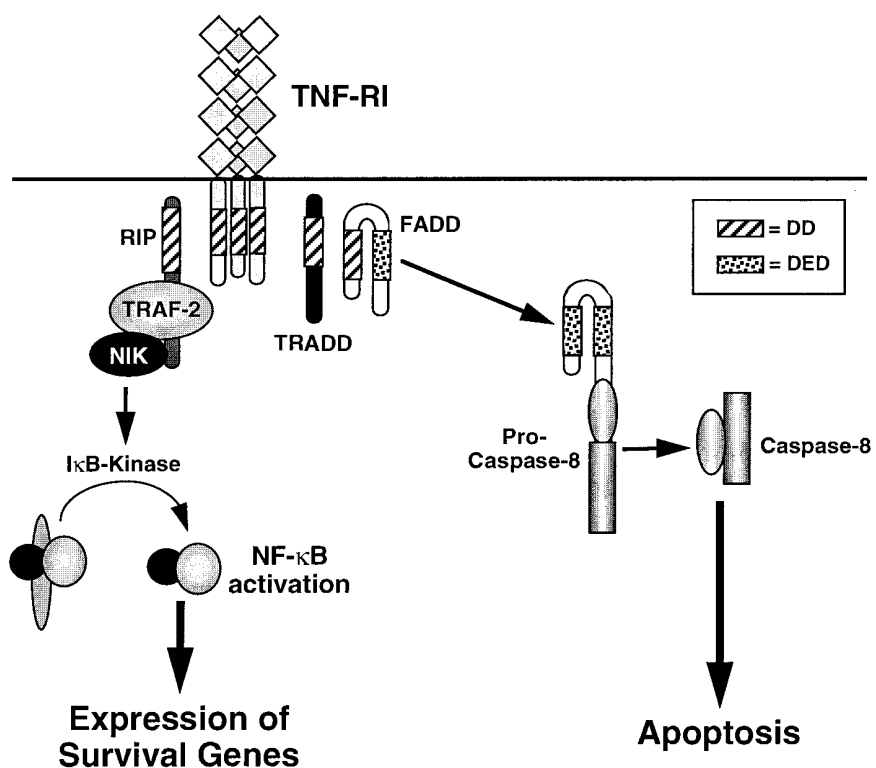

Fig.5. Anti- and pro-apoptotic signaling pathways mediated by TNF-R1. Ligation of TNF-R1 results in two major cellular responses, activation of transcription factor NF- $\kappa \mathrm{B}$ and induction of cell death. NF$\kappa \mathrm{B}$ activation by TNF-R1 involves recruitment of the adaptor proteins RIP and TRAF-2, and the kinase NIK. This event finally results in activation of the multisubunit $\mathrm{I} \kappa \mathrm{B}$ kinase which phosphorylates the NF$\kappa \mathrm{B}$ inhibitor $\mathrm{I} \kappa \mathrm{B}$ at two $\mathrm{N}$-terminal serine residues. Phosphorylated $\mathrm{I} \kappa \mathrm{B}$ dissociates from the inactive NF- $\kappa$ B heterodimer by inducible proteolysis and allows NF- $\kappa$ B to translocate to the nucleus and to activate expression of NF- $\kappa \mathrm{B}$-controlled survival genes. The cytotoxic response of TNF-R1 ligation is mediated by the DD-containing protein TRADD which can interact with FADD and thereby activate the proximal caspase cascade.

Whereas many data favour the idea of Bcl-2 proteins as inhibitors of cytochrome $c$ relocalization, very recent results cast doubt on the hypothesis that cytochrome $c$ release may regulate apoptosis in general. MCF-7 cells which are deficient for caspase-3 were found to be refractory to microinjected cytochrome $c$, although Bcl- $\mathrm{x}_{\mathrm{L}}$ efficiently prevented CD95 and TNF-R1-mediated apoptosis [259]. Furthermore, it has been observed that Bcl-2 inhibits Bax-induced caspase activation and apoptosis, but not cytochrome $c$ release. Bcl-2 was found to confer protection even in response to injected cytochrome $c$ [254]. These findings therefore suggest that effects of Bcl-2 may not be solely explained by the inhibition of cytochrome $c$ release. It is possible that Bcl-2 inhibits apoptosis by binding to cytochrome $c$ or Apaf-1, thereby preventing caspase activation.

It is still very controversial whether Bcl-2 essentially affects apoptosis induced by CD95 or other death receptors. There are certain cell types where Bcl-2 or related proteins provide potent protection against CD95-induced apoptosis [260, 261], while there are other cells in which Bcl-2 is completely ineffective [262, 263]. Since CD95-mediated caspase- 8 activation at the DISC level is not inhibited by Bcl- $\mathrm{x}_{\mathrm{L}}$, execution of apoptosis could be independent of the release of cytochrome $c$ and other pro-apoptotic mitochondrial components. In contrast, Bcl-2 may inhibit cell death in such cells, where execution of apoptosis depends on cytochrome $c$ and Apaf-1-induced activation of executioner caspases [264]. It will be interesting to investigate how the FADD/caspase- 8 pathway is connected to mitochondria and whether caspase- 8 can directly cause mitochondrial swelling, for instance by cleavage of proteins at the outer mitochondrial membrane. 
NF- $\kappa$ B and additional anti-apoptotic mechanisms. Cells contain a variety of other mechanisms which can counteract apoptotic or necrotic cell death. Heat-shock proteins (Hsps) constitute a group of molecules that are induced by multiple stress stimuli and, following overexpression, confer enhanced survival of cells exposed to apoptosis-inducing agents. Overexpression of Hsp70 protects against TNF-induced apoptosis [265] and, likewise, enforced expression of small Hsps confers resistance against oxidative stress, TNF, CD95, staurosporine and anticancer drugs [266]. The molecular mechanism by which Hsps protect against apoptosis is largely undefined. It has been hypothesized that small Hsps protect cells by inhibiting the action of reactive oxygen intermediates, because overexpression led to an increased amount of the antioxidant glutathione and decreased lipid peroxidation. Hsps may also counteract disruption of the microfilament network which often occurs during apoptosis.

Many cell types that are resistant to apoptosis induced by death receptors become sensitive in the presence of inhibitors of macromolecular synthesis. This observation indicates that triggering of a death receptor may simultaneously initiate a genetic programme that blocks cell death. There is now ample evidence to suggest that transcription factor NF- $\kappa \mathrm{B}$ largely controls antiapoptotic gene expression [267]. NF- $\kappa \mathrm{B}$, which was previously known mainly as a mediator of inflammatory gene expression, consists of a heterodimeric complex often composed of p50 and the 65-kDa RelA subunit (Fig. 5). In its inactive state, the complex is sequestered in the cytosol by an inhibitory subunit, called $\mathrm{I} \kappa \mathrm{B}$. Upon stimulation of cells, $\mathrm{I} \kappa \mathrm{B}$ is phosphorylated at $\mathrm{N}$-terminal Ser residues and proteolytically degraded, which then allows NF- $\kappa \mathrm{B}$ to translocate to the nucleus and activate target genes. The signal-induced phosphorylation of $\mathrm{I} \kappa \mathrm{B}$ has been recently shown to involve the TRAF-2-associating kinase NIK (NF- $\kappa \mathrm{B}$-inducing kinase) which subsequently activates the $\mathrm{I} \kappa \mathrm{B}$ kinase (IKK-1/-2) in a multisubunit complex [268].

A first hint for the involvement of NF- $\kappa \mathrm{B}$ in protecting against cell death came from NF- $\kappa$ B RelA-knockout mice which died before birth and showed massive apoptotic degeneration of liver cells [269]. It was further demonstrated that fibroblasts and macrophages from RelA-deficient mice are hypersensitive to TNF-induced cytotoxicity, whereas wild-type cells survive this treatment [270]. In another approach, it was demonstrated that cells were sensitized to TNF, chemotherapeutic drugs and ionizing irradiation, when NF- $\kappa$ B activation was blocked by a dominant-negative $\mathrm{I} \kappa \mathrm{B}$ mutant $[271,272]$. In addition, B-lymphocyte cell lines constitutively express NF- $\kappa \mathrm{B}$, but inactivation of NF$\kappa \mathrm{B}$ by various means induces apoptosis [273].

A general role for NF- $\kappa$ B as a transcription factor that prevents cell death is, however, not established. Apoptosis triggered by CD95 is not countered by NF- $\kappa \mathrm{B}$ [272], presumably because CD95 does not lead to detectable NF- $\kappa$ B activation in most cell types. There are some reports pointing even to a pro-apoptotic role of NF- $\kappa$ B. For instance, NF- $\kappa$ B has been implicated in glutamate-induced toxicity of neurons, as blocking its activation with salicylate protected cells from excitotoxic damage [274]. Apoptosis induced by serum withdrawal was demonstrated to induce NF- $\kappa \mathrm{B}$ activation which was prevented by overexpression of Bcl-2 [275]. Furthermore, Sindbis-virus-induced apoptosis in a carcinoma cell line was shown to require NF- $\kappa \mathrm{B}$ activation, as antisense NF- $\kappa$ B oligonucleotides prevented cell death [276].

The putative anti-apoptotic genes that are activated by NF$\kappa \mathrm{B}$ remain to be identified. Likely candidates are the genes encoding for manganese superoxide dismutase (MnSOD), c-IAP2 and the zinc finger protein A20. Expression of all three genes is induced by TNF. MnSOD, which converts superoxide anion to hydrogen peroxide inside mitochondria, may be involved by providing protection against TNF necrosis which is largely dependent on formation of reactive oxygen intermediates [277]. c-IAP2 is an NF- $\kappa$ B-controlled gene product which, as described above, presumably inhibits apoptosis at the level of either caspases or proximal TNF receptor signal transduction.

Gene expression of A20 is tightly regulated by NF- $\kappa$ B that binds at two $\kappa \mathrm{B}$-binding sites within its promoter [278]. Overexpression of A20 can provide protection against cell death by TNF, but not by serum depletion, oxidative stress or CD95 [279, 280]. Though the biochemical mechanism of action of A20 is unknown, it has been found that A20 interacts with the TNFreceptor-associated proteins TRAF1 and TRAF2 [281]. How A20 inhibits apoptosis, which, as mentioned above, is not mediated by TRAF1/TRAF2 but by TRADD, remains to be determined. It is interesting to note that transfection of A20 in $\mathrm{RelA}^{(-)}$cells does not rescue these cells from TNF-induced apoptosis [270], suggesting that additional resistance genes must be involved. The function of NF- $\kappa \mathrm{B}$ as a regulatory loop that provides protection against apoptosis, has presumably important implications for tumor therapy. If tumor cell sensitivity is controlled by NF- $\kappa$ B, a selective inhibition of NF- $\kappa$ B may result in improved efficacy of anticancer therapy.

\section{Conclusions}

This review describes the different death receptors and the pathways that are used either to induce or to counteract apoptosis. Certainly, the rapid discovery of the great variety of different death receptors with their multitude of control points proceeds well ahead of our understanding of their role in the organism. Our present view of the different functions of the various death systems is still restricted and it can be anticipated that even more components of their signaling pathways will be identified. A major objective of future research will be to study the biological function of death systems and to address questions such as why there are different death systems, how they operate and what ensures their specificity. Another challenge is to apply the knowledge of death receptor networks to therapy. Therapeutic targeting of certain death pathways would be beneficial for very diverse diseases including AIDS, hepatitis, neurodegeneration, multiple sclerosis, stroke, myocardial ischemia and others. While the goal of treating these diseases is to prevent cell death, the major challenge in treating cancer is to kill cells that are resistant to available chemotherapy. Since the failure to undergo apoptosis is often associated with drug resistance, direct activation of physiological death pathways may be an effective strategy to kill tumor cells.

This work was supported by grants from the Deutsche Forschungsgemeinschaft (SFB 364/A7, Schu 1180/1-1) and the European Union (Biomed2). D. F. gratefully acknowledges a fellowship from FEBS and the Vigoni (DAAD/CRUI) programme, and S. W. from the Bundesministerium für Bildung und Forschung.

\section{References}

1. Anderson, D. M., Maraskovsky, E., Billingsley, W. L., Dougall, W. C., Tometsko, M. E., Roux, E. R., Teepe, M. C., DuBose, R. F., Cosman, D. \& Galibert, L. (1997) A homologue of the TNF receptor and its ligand enhance T-cell growth and dendritic cell function, Nature 390, 175-179.

2. Bodmer, J. L., Burns, K., Schneider, P., Hofmann, K., Steiner, V., Thome, M., Bornand, T., Hahne, M., Schroter, M., Becker, K., Wilson, A., French, L. E., Browning, J. L., MacDonald, H. R. \& Tschopp, J. (1997) TRAMP, a novel apoptosis-mediating receptor with sequence homology to tumor necrosis factor receptor 1 and Fas (Apo-1/CD95), Immunity 6, 79-88. 
3. Nocentini, G., Giunchi, L., Ronchetti, S., Krausz, L. T., Bartoli, A., Moraca, R., Migliorati, G. \& Riccardi, C. (1997) A new member of the tumor necrosis factor/nerve growth factor receptor family inhibits T cell receptor-induced apoptosis, Proc. Natl Acad. Sci. USA 94, 6216-6221.

4. Itoh, N., Yonehara, S. I. A., Yonehara, M., Mizushima, S., Sameshima, M., Hase, A., Seto, Y. \& Nagata, S. (1991) The polypeptide encoded by the cDNA for human cell surface antigen Fas can mediate apoptosis, Cell 66, 233-243.

5. Oehm, A., Behrmann, I., Falk, W., Pawlita, M., Maier, G., Klas, C., Li Weber, M., Richards, S., Dhein, J., Trauth, B. C., Pansting, I. K. \& Krammer, P. H. (1992) Purification and molecular cloning of the APO-1 cell surface antigen, a member of the tumor necrosis factor/nerve growth factor receptor superfamily. Sequence identity with the Fas antigen, J. Biol. Chem. 267, 10709-10715.

6. Tartaglia, L. A., Ayres, T. M., Wong, G. H. \& Goeddel, D. V. (1993) A novel domain within the $55 \mathrm{kd}$ TNF receptor signals cell death, Cell 74, 845-853.

7. Itoh, N. \& Nagata, S. (1993) A novel protein domain required for apoptosis. Mutational analysis of human Fas antigen, J. Biol. Chem. 268, 10932-10937.

8. Chinnaiyan, A. M., O’Rourke, K., Yu, G. L., Lyons, R. H., Garg, M., Duan, D. R., Xing, L., Gentz, R., Ni, J. \& Dixit, V. M. (1996) Signal transduction by DR3, a death domain-containing receptor related to TNFR-1 and CD95, Science 274, 990-992.

9. Kitson, J., Raven, T., Jiang, Y. P., Goeddel, D. V., Giles, K. M., Pun, K. T., Grinham, C. J., Brown, R. \& Farrow, S. N. (1996) A death-domain-containing receptor that mediates apoptosis, Nature 384, 372-375.

10. Marsters, S. A., Sheridan, J. P., Donahue, C. J., Pitti, R. M., Gray, C. L., Goddard, A. D., Bauer, K. D. \& Ashkenazi, A. (1996) Apo-3, a new member of the tumor necrosis factor receptor family, contains a death domain and activates apoptosis and NF- $\kappa \mathrm{B}$, Curr. Biol. 6, 1669-1676.

11. Screaton, G. R., Xu, X. N., Olsen, A. L., Cowper, A. E., Tan, R., McMichael, A. J. \& Bell, J. I. (1997) LARD: a new lymphoidspecific death domain containing receptor regulated by alternative pre-mRNA splicing, Proc. Natl Acad. Sci. USA 94, 46154619.

12. Pan, G., O’Rourke, K., Chinnaiyan, A. M., Gentz, R., Ebner, R., Ni, J. \& Dixit, V. M. (1997) The receptor for the cytotoxic ligand TRAIL, Science 276, 111-113.

13. Pan, G., Ni, J., Wei, Y. F., Yu, G., Gentz, R. \& Dixit, V. M. (1997) An antagonist decoy receptor and a death domain-containing receptor for TRAIL, Science 277, 815-818.

14. Sheridan, J. P., Marsters, S. A., Pitti, R. M., Gurney, A., Skubatch, M., Badwin, D., Ramakrishnan, L., Gray, C. L., Baker, K., Wood, W. I., Goddard, A. D., Godowski, P. \& Ashkenazi, A. (1997) Control of TRAIL-induced apoptosis by a family of signaling and decoy receptors, Science 277, 818-821.

15. Walczak, H., Degli Esposti, M. A., Johnson, R. S., Smolak, P. J., Waugh, J. Y., Boiani, N., Timour, M. S., Gerhart, M. J., Schooley, K. A., Smith, C. A., Goodwin, R. G. \& Rauch, C. T. (1997) TRAIL-R2: a novel apoptosis-mediating receptor for TRAIL, EMBO J. 16, 5386-5397.

16. MacFarlane, M., Ahmadi, M., Srinivasula, S. M., Fernades Alnemri, T., Cohen, G. M. \& Alnemri, E. S. (1997) Identification of two novel receptors for the cytotoxic ligand TRAIL, J. Biol. Chem. 272, 25417-25420.

17. Chaudhary, P. M., Eby, M., Jasmin, A., Bookwalter, A., Murray, J. \& Hood, L. (1997) Death receptor 5, a new member of the TNFR family, and DR4 induce FADD-dependent apoptosis and activate the NF- $\kappa \mathrm{B}$ pathway, Immunity $7,821-830$.

18. Schneider, P., Thome, M., Burs, K., Bodmer, J. L., Hofman, K., Kataoka, T., Holler, N. \& Tschopp, J. (1997) TRAIL receptors 1 (DR4) and 2 (DR5) signal FADD-dependent apoptosis and activate $\mathrm{NF}-\kappa \mathrm{B}$, Immunity 7, 831-836.

19. Degli-Esposti, M. A., Smolak, P. J., Walczak, H., Waugh, J., Huang, C. P., DuBose, R. F., Goodwin, R. G. \& Smith, C. A. (1997) Cloning and characterization of TRAIL-R3, a novel member of the emerging TRAIL receptor family, J. Exp. Med. 186, 11651170 .
20. Degli-Esposti, M. A., Dougall, W. C., Smolak, P. J., Waugh, J. Y., Smith, C. A. \& Goodwin, R. G. (1997) The novel receptor TRAIL-R4 induces NF- $\kappa$ B and protects against TRAIL-mediated apoptosis, yet retains an incomplete death domain, Immunity 7, 813-820.

21. Marsters, S. A., Sheridan, J. P., Pitti, R. M., Skubatch, M., Baldwin, D., Yuan, J., Gurney, A., Goddard, A. D., Godowski, P. \& Ashkenazi, A. (1997) A novel receptor for Apo2L/TRAIL contains a truncated death domain, Curr. Biol. 7, 1003-1006.

22. Mongkolsapaya, J., Cowper, A. E., Xu, X. N., Morris, G., McMichael, A. J., Bell, J. I. \& Screaton, G. R. (1998) Lymphocyte inhibitor of TRAIL: a new receptor protecting lymphocytes from the death ligand TRAIL, J. Immunol. 160, 3-6.

23. Beutler, B. \& van Huffel, C. (1994) Unraveling function in the TNF ligand and receptor families, Science 264, 667-668.

24. Wiley, S. R., Schooley, K., Smolak, P. J., Din, W. S., Huang, C. P., Nicholl, J. K., Sutherland, G. R., Smith, T. D., Rauch, C. \& Smith, C. A. (1995) Identification and characterization of a new member of the TNF family that induces apoptosis, Immunity 3, $673-682$.

25. Eck, M. J., Ultsch, M., Rinderknecht, E., de Vos, A. M. \& Sprang, S. R. (1992) The structure of human lymphotoxin (tumor necrosis factor- $\beta$ ) at 1.9- $\AA$ resolution, J. Biol. Chem. 267, 2119-2122.

26. Jones, E. Y., Stuart, D. I. \& Walker, N. P. (1992) Crystal structure of TNF, Immunol. Ser. 56, 93-127.

27. Banner, D. W., D’Arcy, A., Janes, W., Gentz, R., Schoenfeld, H. J., Broger, C., Loetscher, H. \& Lesslauer, W. (1993) Crystal structure of the soluble human $55 \mathrm{kd}$ TNF receptor-human TNF $\beta$ complex: implications for TNF receptor activation, Cell 73, 431-445.

28. Dhein, J., Daniel, P. T., Trauth, B. C., Oehm, A., Moeller, P. \& Krammer, P. H. (1992) Induction of apoptosis by monoclonal antibody anti-APO-1 class switch variants is dependent on crosslinking of APO-1 cell surface antigens, J. Immunol. 149, 31663173.

29. Black, R. A., Rauch, C. T., Kozlosky, C. J., Peschon, J. J., Slack, J. L., Wolfson, M. F., Castner, B. J., Stocking, K. L., Reddy, P., Srinivasan, S., Nelson, N., Boiani, N., Schooley, K. A., Gerhart, M., Davis, R., Fitzner, J. N., Johnson, R. S., Paxton, R. J., March, C. J. \& Cerretti, D. P. (1997) A metalloproteinase disintegrin that releases tumour-necrosis factor- $\alpha$ from cells, Nature 385, 729-733.

30. Moss, M. L., Jin, S. L., Milla, M. E., Burkhart, W., Carter, H. L., Chen, W. J., Clay, W. C., Didsbury, J. R., Hassler, D., Hoffman, C. R., Kost, T. A., Lambert, M. H., Leesnitzer, M. A., McCauley, P., McGeehan, G., Mitchell, J., Moyer, M., Pahel, G., Rocque, W., Overton, L. K., Schoenen, F., Seaton, T., Su, J. L., Warner, J., Willard, D. \& Becherer, J. D. (1997) Cloning of a disintegrin metalloproteinase that processes precursor tumour-necrosis factor-alpha, Nature 385, 733-736.

31. Vassalli, P. (1992) The pathopyhsiology of tumor necrosis factors, Annu. Rev. Immunol. 10, 411-452.

32. Tracey, K. J. \& Cerami, A. (1993) Tumor necrosis factor, other cytokines and disease, Annu. Rev. Cell Biol. 9, 317-343.

33. Bazzoni, F. \& Beutler, B. (1996) The tumor necrosis factor ligand and receptor families, New Engl. J. Med. 334, 1717-1725.

34. Fiers, W., Beyaert, R., Boone, E., Cornelis, S., Declercq, W., Decoster, E., Denecker, G., Depuydt, B., De Valck, D., De Wilde, G., Goossens, V., Grooten, J., Haegeman, G., Heyninck, K., Penning, L., Plaisance, S., Vancompernolle, K., Van Criekinge, W., Vandenabeele, P., Vanden Berghe, W., Van de Craen, M., Vandevoorde, V. \& Vercammen, D. (1996) TNF induced intracellular signaling leading to gene induction or to cytotoxicity by necrosis or by apoptosis, J. Inflamm. 47, 67-75.

35. Trauth, B. C., Klas, C., Peters, A. M., Matzku, S., Moeller, P., Falk, W., Debatin, K. M. \& Krammer, P. H. (1989) Monoclonal antibody-mediated tumor regression by induction of apoptosis, Science 245, 301-305.

36. Yonehara, S., Ishii, A. \& Yonehara, M. (1989) A cell killing monoclonal antibody (anti-Fas) to a cell surface antigen co-downregulated with the receptor of tumor necrosis factor, J. Exp. Med. $169,1747-1756$.

37. Krammer, P. H., Dhein, J., Walczak, H., Behrmann, I., Mariani, S., Matiba, B., Fath, M., Daniel, P. T., Knipping, E., Westendorp, 
M. O., Stricker, K., Bäumler, C., Hellbardt, S., Germer, M. \& Debatin, K. M. (1994) The role of APO-1-mediated apoptosis in the immune system, Immunol. Rev. 142, 175-191.

38. Schulze-Osthoff, K. (1994) The Fas/APO-1 receptor and its deadly ligand, Trends Cell Biol 4, 421-426.

39. Nagata, S. (1997) Apoptosis by death factor, Cell 88, 355-365.

40. Watanabe-Fukunaga, R., Brannan, C. I., Copeland, N. G., Jenkins, N. A. \& Nagata, S. (1992) Lymphoproliferation disorder in mice explained by defects in Fas antigen that mediates apoptosis, $\mathrm{Na}$ ture 356, 314-317.

41. Takahashi, T., Tanaka, M., Brannan, C. I., Jenkins, N. A., Copeland, N. G., Suda, T. \& Nagata, S. (1994) Generalized lymphoproliferative disease in mice, caused by a point mutation in the Fas ligand, Cell 76, 969-976.

42. Adachi, M., Watanabe Fukunaga, R. \& Nagata, S. (1993) Aberrant transcription caused by the insertion of an early transposable element in an intron of the Fas antigen gene of lpr mice, Proc. Natl Acad. Sci. USA 90, 1756-1760.

43. Fisher, G. H., Rosenberg, F. J., Straus, S. E., Dale, J. K., Middleton, L. A., Lin, A. Y., Strober, W., Lenardo, M. J. \& Puck, J. M. (1995) Dominant interfering Fas gene mutations impair apoptosis in a human autoimmune lymphoproliferative syndrome, Cell 81, 935-946.

44. Rieux-Laucat, F., Le Deist, F., Hivroz, C., Roberts, I. A., Debatin, K. M., Fischer, A. \& de Villartay, J. P. (1995) Mutations in Fas associated with human lymphoproliferative syndrome and autoimmunity, Science 268, 1347-1349.

45. Drappa, J., Vaishnaw, A. K., Sullivan, K. E., Chu, J. L. \& Elkon, K. B. (1996) The Canale-Smith syndrome: an inherited autoimmune disorder associated with defective lymphocyte apoptosis and mutations in the Fas gene, N. Engl. J. Med. 335, 16431649.

46. Dhein, J., Walczak, H., Baeumler, C., Debatin, K. M. \& Krammer, P. H. (1995) Autocrine T-cell suicide mediated by APO-1/ (Fas/ CD95), Nature 373, 438-441.

47. Brunner, T., Mogil, R. J., LaFace, D., Yoo, N. J., Mahboubi, A., Echeverri, F., Martin, S. J., Force, W. R., Lynch, D. H., Ware, C. F. \& Green, D. R. (1995) Cell-autonomous Fas (CD95)/Fasligand interaction mediates activation-induced apoptosis in $\mathrm{T}$ cell hybridomas, Nature 373, 441-444.

48. Ju, S. T., Panka, D. J., Cui, H., Ettinger, R., el Khatib, M., Sherr, D. H., Stanger, B. Z. \& Marshak Rothstein, A. (1995) Fas (CD95)/FasL interactions required for programmed cell death after T-cell activation, Nature 373, 444-448.

49. Rouvier, E. \& Luciani, M. G. P. (1993) Fas involvement in $\mathrm{Ca}^{2+}$ independent T cell-mediated cytotoxicity, J. Exp. Med. 177, $195-200$

50. Hanabuchi, S., Koyanagi, M., Kawasaki, A., Shinohara, N., Matsuzawa, A., Nishimura, Y., Kobayashi, Y., Yonehara, S., Yagita, H. \& Okumura, K. (1994) Fas and its ligand in a general mechanism of T cell mediated cytotoxicity, Proc. Natl Acad. Sci. USA 91, 4930-4934.

51. Herron, L. R., Eisenberg, R. A., Roper, E., Kakkanaiah, V. N., Cohen, P. L. \& Kotzin, B. L. (1993) Selection of the T cell receptor repertoire in Lpr mice, J. Immunol. 151, 3450-3459.

52. Singer, G. G. \& Abbas, A. K. (1994) The Fas antigen is involved in peripheral but not thymic deletion of $\mathrm{T}$ lymphocytes in $\mathrm{T}$ cell receptor transgenic mice, Immunity 1, 365-371.

53. Cornall, R. J., Goodnow, C. C. \& Cyster, J. G. (1995) The regulation of self-reactive B cells, Curr. Opin. Immunol. 7, 804-811.

54. Westendorp, M. O., Frank, R., Ochsenbauer, C., Stricker, K., Dhein, J., Walczak, H., Debatin, K. M. \& Krammer, P. H. (1995) Sensitization of T cells to CD95-mediated apoptosis by HIV-1 Tat and gp120, Nature 375, 497-500.

55. Li, C. J., Friedman, D. J., Wang, C., Metelev, V. \& Pardee, A. B. (1995) Induction of apoptosis in uninfected lymphocytes by HIV-1 Tat protein, Science 268, 429-431.

56. Katsikis, P. D., Wunderlich, E. S., Smith, C. A. \& Herzenberg, L. A. (1995) Fas antigen stimulation induces marked apoptosis of $\mathrm{T}$ lymphocytes in human immunodeficiency virus-infected individuals, J. Exp. Med. 181, 2029-2036.

57. Debatin, K. M., Fahrig-Faissner, A., Enenkel-Stoodt, S., Kreuz, W., Benner, A. \& Krammer, P. H. (1994) High expression of APO-1
(CD95) on T lymphocytes from human immunodeficiency virus1-infected children, Blood 83, 3101-3103.

58. Griffith, T. S., Brunner, T., Fletcher, S. M., Green, D. R. \& Ferguson, T. A. (1995) Fas ligand-induced apoptosis as a mechanism of immune privilege, Science 270, 1189-1192.

59. Bellgrau, D., Gold, D., Selawry, H., Moore, J., Franzusoff, A. \& Duke, R. C. (1995) A role for CD95 ligand in preventing graft rejection, Nature 377, 630-632.

60. Griffith, T. S., Yu, X., Herndon, J. M., Green, D. R. \& Ferguson, T. A. (1996) CD95-induced apoptosis of lymphocytes in an immune privileged site induces immunological tolerance, Immunity 5, 716.

61. Stuart, P. M., Griffith, T. S., Usui, N., Pepose, J., Yu, X. \& Ferguson, T. A. (1997) CD95 ligand (FasL)-induced apoptosis is necessary for corneal allograft survival, J. Clin. Invest. 99, 396-402.

62. Lau, H. T., Yu, M., Fontana, A. \& Stoeckert, C. J. J. (1996) Prevention of islet allograft rejection with engineered myoblasts expressing FasL in mice, Science 273, 109-112.

63. Selawry, H. P. \& Cameron, D. F. (1993) Sertoli cell-enriched fractions in successful islet cell transplantation, Cell. Transplant. 2, $123-129$.

64. Hahne, M., Rimoldi, D., Schroter, M., Romero, P., Schreier, M., French, L. E., Schneider, P., Bornand, T., Fontana, A., Lienard, D., Cerottini, J. \& Tschopp, J. (1996) Melanoma cell expression of Fas (Apo-1/CD95) ligand: implications for tumor immune escape, Science 274, 1363-1366.

65. O'Connell, J., O'Sullivan, G. C., Collins, J. K. \& Shanahan, F. (1996) The Fas counterattack: Fas-mediated T cell killing by colon cancer cells expressing Fas ligand, J. Exp. Med. 184, 1075-1082.

66. Strand, S., Hofmann, W. J., Hug, H., Mueller, M., Otto, G., Strand, D., Mariani, S. M., Stremmel, W., Krammer, P. H. \& Galle, P. R. (1996) Lymphocyte apoptosis induced by CD95 (APO-1/Fas) ligand-expressing tumor cells. A mechanism of immune evasion? Nat. Med. 2, 1306-1307.

67. Niehans, G. A., Brunner, T., Frizelle, S. P., Liston, J. C., Salerno, C. T., Knapp, D. J., Green, D. R. \& Kratzke, R. A. (1997) Human lung carcinomas express Fas ligand, Cancer Res. 57, 1007-1012.

68. Saas, P., Walker, P. R., Hahne, M., Quiquerez, A. L., Schnuriger, V., Perrin, G., French, L., Van Meir, E. G., de Tribolet, N., Tschopp, J. \& Dietrich, P. Y. (1997) Fas ligand expression by astrocytoma in vivo: maintaining immune privilege in the brain? J. Clin. Invest. 99, 1173-1178.

69. Shiraki, K., Tsuji, N., Shioda, T., Isselbacher, K. J. \& Takahashi, H. (1997) Expression of Fas ligand in liver metastases of human colonic adenocarcinomas, Proc. Natl Acad. Sci. USA 94, 64206425.

70. Tanaka, M., Suda, T., Haze, K., Nakamura, N., Sato, K., Kimura, F., Motoyoshi, K., Mizuki, M., Tagawa, S., Ohga, S., Hatake, K., Drumond, A. H. \& Nagata, S. (1996) Fas ligand in human serum, Nat. Med. 2, 317-322.

71. Galle, P. R., Hofmann, W. J., Walczak, H., Schaller, H., Otto, G., Stremmel, W., Krammer, P. H. \& Runkel, L. (1995) Involvement of the CD95 (APO-1/Fas) receptor and ligand in liver damage, $J$. Exp. Med. 182, 1223-1230.

72. Braun, M. Y., Lowin, B., French, L., Acha Orbea, H. \& Tschopp, J. (1996) Cytotoxic T cells deficient in both functional fas ligand and perforin show residual cytolytic activity yet lose their capacity to induce lethal acute graft-versus-host disease, J. Exp. Med. 183, $657-661$.

73. Chervonsky, A. V., Wang, Y., Wong, F. S., Flavell, R. A., Janeway, C. A. Jr \& Matis, L. A. (1997) The role of Fas in autoimmune diabetes, Cell 89, 17-24.

74. Sabelko, K. A., Kelly, K. A., Nalm, M. H., Cross, A. H. \& Russell, J. H. (1997) Fas and Fas ligand enhance the pathogenesis of experimental allergic encephalomyelitis but are not essential for immune privilege in the central nervous system, J. Immunol. 159, 3096-3099.

75. Waldner, H., Sobel, R. A., Howard, E. \& Kuchroo, V. K. (1997) Fas and FasL deficient mice are resistant to induction of autoimmune encephalomyelitis, J. Immunol. 159, 3100-3103.

76. Allison, J., Georgiou, H. M., Strasser, A. \& Vaux, D. L. (1997) Transgenic expression of CD95 ligand on islet $\beta$-cells induces a granulocytic infiltration but does not confer immune privilege upon islet allografts, Proc. Natl Acad. Sci. USA 94, 3943-3947. 
77. Seino, K., Kayagaki, N., Okumura, K. \& Yagita, H. (1997) Antitumor effect of locally produced CD95 ligand, Nat. Med. 3, 165170.

78. Abreu-Martin, M. T., Vidrich, A., Lynch, D. H. \& Targan, S. R. (1995) Divergent induction of apoptosis and IL-8 secretion in HT29 cells in response to TNF- $\alpha$ and ligation of Fas antigen, J. Iтmиnol. 155, 4147-4154.

79. Alderson, M. R., Armitage, R. J., Maraskovsky, E., Tough, T. W., Roux, E., Schooley, K., Ramsdell, F. \& Lynch, D. H. (1993) Fas transduces activation signals in normal human T lymphocytes, $J$. Exp. Med. 178, 2231-2235.

80. Mapara, M. Y., Bargou, R., Zugck, C., Dohner, H., Ustaoglu, F., Jonker, R. R., Krammer, P. H. \& Dorken, B. (1993) APO-1 mediated apoptosis or proliferation in human chronic B lymphocytic leukemia: correlation with bcl-2 oncogene expression, Eur. J. Immunol. 23, 702-708.

81. Aggarwal, B. B., Singh, S., LaPushin, R. \& Totpal, K. (1995) Fas antigen signals proliferation of normal human diploid fibroblasts and its mechanism is different from tumor necrosis factor receptor, FEBS Lett. 364, 5-8.

82. Freiberg, R. A., Spencer, D. M., Choate, K. A., Duh, H. J., Schreiber, S. L., Crabtree, G. R. \& Khavari, P. A. (1997) Fas signal transduction triggers either proliferation or apoptosis in human fibroblasts, J. Invest. Dermatol. 108, 215-219.

83. Schulze-Osthoff, K., Krammer, P. H. \& Droege, W. (1994) Divergent signaling via APO-1/Fas and the TNF receptor, two homologous molecules involved in physiological cell death, EMBO J. 13, $4587-4596$.

84. Giordano, C., Stassi, G., De Maria, R., Todaro, M., Richiusa, P., Papoff, G., Ruberti, G., Bagnasco, M., Testi, R. \& Galluzzo, A. (1997) Potential involvement of Fas and its ligand in the pathogenesis of Hashimoto's thyroiditis, Science 275, 960-963.

85. Owen-Schaub, L. B., Zhang, W., Cusack, J. C., Angelo, L. S., Santee, S. M., Fujiwara, T., Roth, J. A., Deisseroth, A. B., Zhang, W. W. Kruzel, E. \& Radinsky, R. (1995) Wild-type human p53 and a temperature-sensitive mutant induce Fas/APO-1 expression, Mol. Cell Biol. 15, 3032-3040.

86. Huber, A. O., Zoernig, M., Lyon, D., Suda, T., Nagata, S. \& Evan, G. I. (1997) Requirement for the CD95 receptor-ligand pathway in cMyc-induced apoptosis, Science 278, 1305-1309.

87. Bissonnette, R. P., McGahon, A., Mahboubi, A. \& Green, D. R. (1994) Functional Myc-Max heteodimer is required for activation-induced apoptosis in T cell hybridomas, J. Exp. Med. 180, $2413-2418$

88. Friesen, C., Herr, I., Krammer, P. H. \& Debatin, K. M. (1996) Involvement of the CD95 (APO-1/Fas) receptor/ligand system in drug induced apoptosis in leukemia cells, Nat. Med. 2, 574-577.

89. Müller, M., Strand, S., Hug, H., Heinemann, E. M., Walczak, H., Hofmann, W. J., Stremmel, W., Krammer, P. H. \& Galle, P. R. (1997) Drug-induced apoptosis in hepatoma cells is mediated by the CD95 (APO-1/Fas) receptor/ligand system and involves activation of wild-type p53, J. Clin. Invest. 99, 403-413.

90. Fulda, S., Sieverts, H., Friesen, C., Herr, I. \& Debatin, K. M. (1997) The CD95 (APO-1/Fas) system mediates drug-induced apoptosis in neuroblastoma cells, Cancer Res. 57, 3823-3829.

91. Eischen, C. M., Kottke, T. J., Martins, L. M., Basi, G. S., Tung, J. S., Earnshaw, W. C., Leibson, P. J. \& Kaufmann, S. H. (1997) Comparison of apoptosis in wild-type and Fas-resistant cells: chemotherapy-induced apoptosis is not dependent on Fas/Fas ligand interactions, Blood 90, 935-943.

92. Gamen, S., Anel, A., Lasierra, P., Alava, M. A., Martinez Lorenzo, M. J., Pineiro, A. \& Naval, J. (1997) Doxorubicin-induced apoptosis in human T-cell leukemia is mediated by caspase- 3 activation in a Fas-independent way, FEBS Lett. 417, 360-364.

93. Rehemtulla, A., Hamilton, C. A., Chinnaiyan, A. M. \& Dixit, V. M. (1997) Ultraviolet radiation-induced apoptosis is mediated by activation of CD-95 (Fas/APO-1), J. Biol. Chem. 272, 2578325786

94. Aragane, Y., Kulms, D., Metze, D., Wilkes, G., Poeppelmann, B., Luger, T. A. \& Schwarz, T. (1998) Ultraviolet light induces apoptosis via activation of CD95 (Fas/APO-1) independently from its ligand CD95L, J. Cell Biol. 140, 171-182.
95. Carswell, E. A., Old, L. J., Kassel, R. L., Green, S., Fiore, N. \& Williamson, B. (1975) An endotoxin-induced factor that causes necrosis of tumors, Proc. Natl Acad. Sci. USA 72, 3666-3670.

96. Beutler, B., Greewald, D., Hulmes, J. D., Chang, M., Pan, Y., Mathison, J., Ulevitch, R. \& Cerami, A. (1985) Identity of tumor necrosis factor and the macrophage-secreted factor cachectin, Nature $316,552-554$.

97. Tartaglia, L. A., Weber, R. F., Figari, I. S., Reynolds, C., Palladino, M. A. J. \& Goeddel, D. V. (1991) The two different receptors for tumor necrosis factor mediate distinct cellular responses, Proc. Natl Acad. Sci. USA 88, 9292-9296.

98. Tartaglia, L. A., Pennica, D. \& Goeddel, D. V. (1993) Ligand passing: the $75-\mathrm{kDa}$ tumor necrosis factor (TNF) receptor recruits TNF for signaling by the 55-kDa TNF receptor, J. Biol. Chem. 268, 18542-18548.

99. Wong, G. H., Tartaglia, L. A., Lee, M. S. \& Goeddel, D. V. (1992) Antiviral activity of tumor necrosis factor is signaled through the 55-kDa type I TNF receptor, J. Immunol. 149, 3350-3353.

100. Vandenabeele, P., Declercq, W., Vanhaesebroeck, B., Grooten, J. \& Fiers, W. (1995) Both TNF receptors are required for TNF-mediated induction of apoptosis in PC60 cells, J. Immunol. 154, 29042913.

101. Grell, M., Douni, E., Wajant, H., Lohden, M., Clauss, M., Maxeiner, B., Georgopoulos, S., Lesslauer, W., Kollias, G., Pfizenmaier, K. \& Scheurich, P. (1995) The transmembrane form of tumor necrosis factor is the prime activating ligand of the $80 \mathrm{kDa}$ tumor necrosis factor receptor, Cell 83, 793-802.

102. Pasparakis, M., Alexopoulou, L., Episkopou, V. \& Kollias, G. (1996) Immune and inflammatory responses in TNF alpha-deficient mice: a critical requirement for TNF alpha in the formation of primary B cell follicles, follicular dendritic cell networks and germinal centers, and in the maturation of the humoral immune response, J. Exp. Med. 184, 1397-1411.

103. Marino, M. W., Dunn, A., Grail, D., Inglese, M., Noguchi, Y., Richards, E., Jungbluth, A., Wada, H., Moore, M., Williamson, B., Basu, S. \& Old, L. (1997) Characterization of tumor necrosis factor-deficient mice, Proc. Natl Acad. Sci. USA 94, 8093-8098.

104. Pasparakis, M., Alexopoulou, L., Grell, M., Pfizenmaier, K., Bluethmann, H. \& Kollias, G. (1997) Peyer's patch organogenesis is intact yet formation of B lymphocyte follicles is defective in peripheral lymphoid organs of mice deficient for tumor necrosis factor and its 55-kDa receptor, Proc. Natl Acad. Sci. USA 94, 63196323

105. Rothe, M., Pan, M. G., Henzel, W. J., Ayres, T. M. \& Goeddel, D. V. (1995) The TNFR2-TRAF signaling complex contains two novel proteins related to baculoviral inhibitor of apoptosis proteins, Cell $83,1243-1252$.

106. Garcia, I., Miyazaki, Y., Araki, K., Araki, M., Lucas, R., Grau, G. E., Milon, G., Belkaid, Y., Montixi, C., Lesslauer, W. \& Vassalli, P. (1995) Transgenic mice expressing high levels of soluble TNF-R1 fusion protein are protected from lethal septic shock and cerebral malaria, and are highly sensitive to Listeria monocytogenes and Leishmania major infections, Eur. J. Immunol. 25, 2401-2407.

107. Shimamoto, Y., Chen, R. L., Bollon, A., Chang, A. \& Khan, A. (1988) Monoclonal antibodies against human recombinant tumor necrosis factor: prevention of endotoxic shock, Immunol. Lett. 17, $311-317$.

108. Hayward, M. \& Fiedler Nagy, C. (1987) Mechanisms of bone loss: rheumatoid arthritis, periodontal disease and osteoporosis, Agents Actions 22, 251-254.

109. Marsters, S. A., Pitti, R. M., Donahue, C. J., Ruppert, S., Bauer, K. D. \& Ashkenazi, A. (1996) Activation of apoptosis by Apo-2 ligand is independent of FADD but blocked by CrmA, Curr. Biol. 6, 750-752.

110. Katsikis, P. D., Garciaojeda, M. E., Torresroca, J. F., Tijoe, I. M., Smith, C. A., Herzenberg, L. A. \& Herzenberg, L. A. (1997) Interleukin- $1 \beta$ converting enzyme like protease involvement in Fas induced and activation induced peripheral blood $\mathrm{T}$ cell apoptosis in HIV infection: TNF related apoptosis inducing ligand can mediate activation induced T cell death in HIV infection, J. Exp. Med. $186,1365-1372$.

111. Jeremias, I., Herr, I., Boehler, T. \& Debatin, K.-M. (1998) TRAIL/ Apo-2 ligand-induced apoptosis in human T cells, Eur. J. Immunol. 28, 143-152. 
112. Huang, B., Eberstadt, M., Olejniczak, E. T., Meadows, R. P. \& Fesik, S. W. (1996) NMR structure and mutagenesis of the Fas (APO-1/ CD95) death domain, Nature 384, 638-641.

113. Chinnaiyan, A. M., O'Rourke, K., Tewari, M. \& Dixit, V. M. (1995) FADD, a novel death domain-containing protein, interacts with the death domain of Fas and initiates apoptosis, Cell 81, 505-512.

114. Boldin, M. P., Varfolomeev, E. E., Pancer, Z., Mett, I. L., Camonis, J. H. \& Wallach, D. (1995) A novel protein that interacts with the death domain of Fas/APO1 contains a sequence motif related to the death domain, J. Biol. Chem. 270, 7795-7798.

115. Stanger, B. Z., Leder, P., Lee, T. H., Kim, E. \& Seed, B. (1995) RIP: a novel protein containing a death domain that interacts with Fas/ APO-1 (CD95) in yeast and causes cell death, Cell 81, 513-523.

116. Hsu, H., Xiong, J. \& Goeddel, D. V. (1995) The TNF receptor 1-associated protein TRADD signals cell death and NF- $\kappa \mathrm{B}$ activation, Cell 81, 495-504.

117. Park, A. \& Baichwal, V. R. (1996) Systematic mutational analysis of the death domain of the tumor necrosis factor receptor 1-associated protein TRADD, J. Biol. Chem. 271, 9858-9862.

118. Ting, A. T., Pimentel Muinos, F. X. \& Seed, B. (1996) RIP mediates tumor necrosis factor receptor 1 activation of NF- $\kappa$ B but not Fas/ APO-1-initiated apoptosis, EMBO J. 15, 6189-6196.

119. Hsu, H., Huang, J., Shu, H. B., Baichwal, V. \& Goeddel, D. V. (1996) TNF-dependent recruitment of the protein kinase RIP to the TNF receptor-1 signaling complex, Immunity 4, 387-396.

120. Kischkel, F. C., Hellbardt, S., Behrmann, I., Germer, M., Pawlita, M., Krammer, P. H. \& Peter, M. E. (1995) Cytotoxicity-dependent APO-1 (Fas/CD95)-associated proteins form a death-inducing signaling complex (DISC) with the receptor, EMBO J. 14, 55795588 .

121. Muzio, M., Chinnaiyan, A. M., Kischkel, F. C., O'Rourke, K., Shevchenko, A., Ni, J., Scaffidi, C., Bretz, J. D., Zhang, M., Gentz, R., Mann, M., Krammer, P. H., Peter, M. E. \& Dixit, V. M. (1996) FLICE, a novel FADD-homologous ICE/CED-3-like protease, is recruited to the CD95 (Fas/APO-1) death-inducing signaling complex, Cell 85, 817-827.

122. Boldin, M. P., Goncharov, T. M., Goltsev, Y. V. \& Wallach, D. (1996) Involvement of MACH, a novel MORT1/FADD-interacting protease, in Fas/APO-1- and TNF receptor-induced cell death, Cell $85,803-815$.

123. Srinivasula, S. M., Ahmad, M., Fernandes Alnemri, T., Litwack, G. \& Alnemri, E. S. (1996) Molecular ordering of the Fas-apoptotic pathway: the Fas/APO-1 protease Mch5 is a CrmA-inhibitable protease that activates multiple Ced-3/ICE-like cysteine proteases, Proc. Natl Acad. Sci. USA 93, 14486-14491.

124. Alnemri, E. S., Livingston, D. J., Nicholson, D. W., Salvesen, G., Thornberry, N. A., Wong, W. W. \& Yuan, J. (1996) Human ICE/ CED-3 protease nomenclature, Cell 87, 171.

125. Chinnaiyan, A. M., Tepper, C. G., Seldin, M. F., O'Rourke, K., Kischkel, F. C., Hellbardt, S., Krammer, P. H., Peter, M. E. \& Dixit, V. M. (1996) FADD/MORT1 is a common mediator of CD95 (Fas/APO-1) and tumor necrosis factor receptor-induced apoptosis, J. Biol. Chem. 271, 4961-4965.

126. Mariani, S. M., Matiba, B., Armandola, E. A. \& Krammer, P. H. (1997) Interleukin 1 beta-converting enzyme related proteases/ caspases are involved in TRAIL-induced apoptosis of myeloma and leukemia cells, J. Cell Biol. 137, 221-229.

127. Wajant, H., Johannes, F. J., Haas, E., Sieminski, K., Schwenzer, R., Schubert, G., Weiss, T., Grell, M. \& Scheurich, P. (1998) Dominant-negative FADD inhibits TNFR60-, Fas/Apo1- and TRAILR/Apo2-mediated cell death but nto gene induction, Curr. Biol. 8 , 113-116.

128. Duan, H. \& Dixit, V. M. (1997) RAIDD is a new 'death' adaptor molecule, Nature 385, 86-89.

129. Ahmad, M., Srinivasula, S. M., Wang, L., Talanian, R. V., Litwack, G., Fernandes Alnemri, T. \& Alnemri, E. S. (1997) CRADD, a novel human apoptotic adaptor molecule for caspase-2, and FasL/ tumor necrosis factor receptor-interacting protein RIP, Cancer Res. 57, 615-619.

130. Schievella, A. R., Chen, J. H., Graham, J. R. \& Lin, L. L. (1997) MADD, a novel death domain protein that interacts with the type 1 tumor necrosis factor receptor and activates mitogen-activated protein kinase, J. Biol. Chem. 272, 12069-12075.
131. Yang, X., Khoravi Far, R., Chang, H. Y. \& Baltimore, D. (1997) Daxx, a novel Fas-binding protein that activates JNK and apoptosis, Cell 89, 1067-1076.

132. Cohen, G. M. (1997) Caspases: the executioners of apoptosis, Biochem. J. 326, 1-16.

133. Nicholson, D. N. \& Thornberry, N. A. (1997) Caspases: killer proteases, Trends Biochem. Sci. 22, 299-306.

134. Enari, M., Hug, H. \& Nagata, S. (1995) Involvement of an ICE-like protease in Fas-mediated apoptosis, Nature 375, 78-81.

135. Los, M., Van de Craen, M., Penning, L. C., Schenk, H., Westendorp, M., Baeuerle, P. A., Droge, W., Krammer, P. H., Fiers, W. \& Schulze-Osthoff, K. (1995) Requirement of an ICE/CED-3 protease for Fas/APO-1-mediated apoptosis, Nature 375, 81-83.

136. Tewari, M. \& Dixit, V. M. (1995) Fas- and tumor necrosis factorinduced apoptosis is inhibited by the poxvirus crmA gene product, J. Biol. Chem. 270, 3255-3260.

137. Heinkelein, M., Pilz, S. \& Jassoy, C. (1996) Inhibition of CD95 (Fas/ Apo1)-mediated apoptosis by vaccinia virus WR, Clin. Exp. Immunol. 103, 8-14.

138. Yuan, J., Shaham, S., Ledoux, S., Ellis, H. M. \& Horvitz, H. R. (1993) The C. elegans cell death gene ced-3 encodes a protein similar to mammalian interleukin-1 $\beta$-converting enzyme, Cell 75, $641-652$.

139. Medema, J. P., Scaffidi, C., Kischkel, F. C., Shevchenko, A., Mann, M., Krammer, P. H. \& Peter, M. E. (1997) FLICE is activated by association with the CD95 death-inducing signaling complex (DISC), EMBO J. 16, 2794-2804.

140. Muzio, M., Salvesen, G. S. \& Dixit, V. M. (1997) FLICE induced apoptosis in a cell-free system. Cleavage of caspase zymogens, $J$. Biol. Chem. 272, 2952-2956.

141. Orth, K., O’Rourke, K., Salvesen, G. S. \& Dixit, V. M. (1996) Molecular ordering of apoptotic mammalian CED-3/ICE-like proteases, J. Biol. Chem. 271, 20977-20980.

142. Fernandes-Alnemri, T., Takahashi, A., Armstrong, R., Krebs, J., Fritz, L., Tomaselli, K. J., Wang, L., Yu, Z., Croce, C. M., Salveson, G., Earnshaw, W. C., Litwack, G. \& Alnemri, E. S. (1995) Mch3, a novel human apoptotic cysteine protease highly related to CPP32, Cancer Res. 55, 6045-6052.

143. Fernandes-Alnemri, T., Armstrong, R. C., Krebs, J., Srinivasula, S. M., Wang, L., Bullrich, F., Fritz, L. C., Trapani, J. A., Tomaselli, K. J., Litwack, G. \& Alnemri, E. S. (1996) In vitro activation of CPP32 and Mch3 by Mch4, a novel human apoptotic cysteine protease containing two FADD-like domains, Proc. Natl Acad. Sci. USA 93, 7464-7469.

144. Hirata, H., Takahashi, A., Kobayashi, S., Yonehara, S., Sawai, H., Okazaki, T., Yamamoto, K. \& Sasada, M. (1998) Caspases are activated in a branched protease cascade and control distinct downstream processes in Fas-induced apoptosis, J. Exp. Med. 187, $587-600$.

145. Kuida, K., Zheng, T. S., Na, S., Kuan, C., Yang, D., Karasuyama, H., Rakic, P. \& Flavell, R. A. (1996) Decreased apoptosis in the brain and premature lethality in CPP32-deficient mice, Nature 384, $368-372$.

146. Kuida, K., Lippke, J. A., Ku, G., Harding, M. W., Livingston, D. J., Su, M. S. \& Flavell, R. A. (1995) Altered cytokine export and apoptosis in mice deficient in interleukin- $1 \beta$ converting enzyme, Science 267, 2000-2003.

147. Boudreau, N., Sympson, C., Werb, Z. \& Bissell, M. (1995) Suppression of ICE and apoptosis in mammary epithelial cells by extracellular matrix, Science 267, 891-893.

148. Tamura, T., Ishishara, M., Lamphier, M. S., Tanaka, N., Oishi, I., Aizawa, S., Matsuyama, T., Mak, T. W., Taki, S. \& Taniguchi, T. (1995) An IRF-1 dependent pathway of DNA damage-induced apoptosis in mitogen-activated T lymphocytes, Nature 376, 596599.

149. Li, P., Allen, H., Banerjee, S., Franklin, S., Herzog, L., Johnston, C., McDowell, J., Paskind, M., Rodman, L., Salfeld, J., Towne, E., Tracey, D., Wardwell, S., Wie, F.-Y., Wong, K., Kamen, R. \& Seshadri, T. (1995) Mice deficient in IL- $1 \beta$-converting enzyme are defective in production of mature IL- $1 \beta$ and resistant to endotoxic shock, Cell 80, 401-411.

150. Smith, D. J., McGuire, M. J., Tocci, M. J. \& Thiele, D. L. (1997) IL- $1 \beta$ convertase (ICE) does not play a requisite role in apoptosis 
induced in T lymphoblasts by Fas-dependent or Fas-independent CTL effector mechanisms, J. Immunol. 158, 163-170.

151. Tewari, M., Quan, L. T., O'Rourke, K., Desnoyers, S., Zeng, Z., Beidler, D. R., Poirier, G. G., Salvesen, G. S. \& Dixit, V. M. (1995) Yama/CPP32 $\beta$, a mammalian homolog of CED-3, is a CrmA-inhibitable protease that cleaves the death substrate poly(ADP-ribose) polymerase, Cell 81, 801-809.

152. Wang, Z. Q., Stingl, L., Morrison, C., Jantsch, M., Los, M., SchulzeOsthoff, K. \& Wagner, E. F. (1997) PARP is important for genomic stability but dispensable in apoptosis, Genes \& Dev. 11, 23472358 .

153. Rudel, T. \& Bokoch, G. M. (1997) Membrane and morphological changes in apoptotic cells regulated by caspase-mediated activation of PAK2, Science 276, 1571-1574.

154. Enari, M., Sakahiera, H., Yokoyama, H., Okawa, K., Iwamatsu, A. \& Nagata, S. (1998) A caspase-activated DNase that degrades DNA during apoptosis, and its inhibitor ICAD, Nature 391, 43-50.

155. Liu, X., Zou, H., Slaughter, C. \& Wang, X. (1997) DFF, a heterodimeric protein that functions downstream of caspase-3 to trigger DNA fragmentation during apoptosis, Cell 89, 175-184.

156. Zou, H., Henzel, W. J., Liu, X., Lutschg, A. \& Wang, X. (1997) Apaf1, a human protein, homologous to C. elegans Ced-4, participates in cytochrome $c$-dependent activation of caspase-3, Cell 90,405413.

157. Chinnaiyan, A. M., O’Rourke, K., Lane, B. R. \& Dixit, V. M. (1997) Interaction of CED-4 with CED-3 and CED-9: a molecular framework for cell death, Science 275, 1122-1126.

158. Wu, D., Wallen, H. D. \& Nunez, G. (1997) Interaction and regulation of subcellular localization of CED-4 by CED-9, Science 275, $1126-1129$.

159. Hofmann, K., Bucher, P. \& Tschopp, J. (1997) The CARD domain a new apoptotic signalling motif, Trends Biochem. Sci. 22, 155156.

160. Li, P., Nijhawan, D., Budihardjo, I., Srinivasula, S. M., Ahmad, M., Alnemri, E. S. \& Wang, X. (1997) Cytochrome $c$ and dATP-dependent formation of Apaf-1/Caspase-9 complex initiates an apoptotic protease cascade, Cell 91, 479-489.

161. Liu, X., Kim, C. N., Yang, J., Jemmerson, R. \& Wang, X. (1996) Induction of apoptotic program in cell-free extracts: requirement for dATP and cytochrome $c$, Cell 86, 147-157.

162. Deiss, L. P., Galinka, H., Berissi, H., Cohen, O. \& Kimchi, A. (1996) Cathepsin D protease mediates programmed cell death induced by interferon-gamma, Fas/APO-1 and TNF- $\alpha, E M B O$ J. 15, 38613870 .

163. Ruggiero, V., Johnson, S. E. \& Baglioni, C. (1987) Protection from tumor necrosis factor cytotoxicity by protease inhibitors, Cell. Immunol. 107, 317-325.

164. Suffys, P., Beyaert, R., Van Roy, F. \& Fiers, W. (1988) Involvement of a serine protease in tumour necrosis factor-mediated cytotoxicity, Eur. J. Biochem. 178, 257-265.

165. Kumar, S. \& Baglioni, C. (1991) Protection from tumor necrosis factor mediated cytolysis by overexpression of plasminogen activator inhibitor type 2, J. Biol. Chem. 266, 20960-20964.

166. Dickinson, J. L., Bates, E. J., Ferrante, A. \& Antalis, T. M. (1995) Plasminogen activator inhibitor type 2 inhibits tumor necrosis factor- $\alpha$ induced apoptosis, J. Biol. Chem. 270, 27 894-27904.

167. Wright, S. C., Wei, A. S., Zhong, J., Zheng, H., Kinder, D. H. \& Larrick, J. W. (1994) Purification of a 24-kD protease from apoptotic tumor cells that activates DNA fragmentation, J. Exp. Med. 180, $2113-2123$.

168. Wright, S. C., Schellenberger, U., Wang, H., Kinder, D. H., Talhouk, J. W. \& Larrick, J. W. (1997) Activation of CPP32-like proteases is not sufficient to trigger apoptosis. Inhibition of apoptosis by agents that suppress activation of AP24, but not CPP32-like activity, J. Exp. Med. 186, 1107-1117.

169. Vercammen, D., Vandenabeele, P., Beyaert, R., Declercq, W. \& Fiers, W. (1997) Tumour necrosis factor-induced necrosis versus antiFas-induced apoptosis in L929 cells, Cytokine 9, 801-808.

170. Haimovitz-Friedman, A., Kan, C. C., Ehleiter, D., Persaud, R. S., McLoughlin, M., Fuks, Z. \& Kolesnick, R. N. (1994) Ionizing radiation acts on cellular membranes to generate ceramide and initiate apoptosis, J. Exp. Med. 180, 525-535.

171. Bose, R., Verheij, M., Haimovitz Friedman, A., Scotto, K., Fuks, Z. \& Kolesnick, R. (1995) Ceramide synthase mediates daunoru- bicin-induced apoptosis: an alternative mechanism for generating death signals, Cell 82, 405-414.

172. Cifone, M. G., Roncaioli, P., De Maria, R., Camarda, G., Santoni, A., Ruberti, G. \& Testi, R. (1995) Multiple pathways originate at the Fas/APO-1 (CD95) receptor: sequential involvement of phosphatidylcholine-specific phospholipase $\mathrm{C}$ and acidic sphingomyelinase in the propagation of the apoptotic signal, EMBO J. 14 , $5859-5868$.

173. Wiegmann, K., Schutze, S., Machleidt, T., Witte, D. \& Kroenke, M. (1994) Functional dichotomy of neutral and acidic sphingomyelinases in tumor necrosis factor signaling, Cell 78, 1005-1015.

174. Gulbins, E., Bissonnette, R., Mahboubi, A., Martin, S., Nishioka, W., Brunner, T., Baier, G., Baier Bitterlich, G., Byrd, C., Lang, F., Kolesnick, R., Altman, A. \& Green, D. (1995) FAS induced apoptosis is mediated via a ceramide initiated RAS signaling pathway, Immunity 2, 341-351.

175. Adam-Klages, S., Adam, D., Wiegmann, K., Struve, S., Kolanus, W., Schneider-Mergener, J. \& Kroenke, M. (1996) FAN, a novel WDrepeat protein, couples the 555 TNF-receptor to neutral sphingomyelinase, Cell 86, 937-947.

176. Machleidt, T., Kramer, B., Adam, D., Neumann, B., Schuetze, S., Wiegmann, K. \& Kroenke, M. (1997) Function of the p55 tumor necrosis factor receptor 'death domain' mediated by phosphatidylcholine-specific phsopholipase C, J. Exp. Med. 184, 725-733.

177. Santana, P., Pena, L. A., Haimovitz Friedman, A., Martin, S., Green, D., McLoughlin, M., Cordon Cardo, C., Schuchman, E. H., Fuks, Z. \& Kolesnick, R. (1996) Acid sphingomyelinase-deficient human lymphoblasts and mice are defective in radiation-induced apoptosis, Cell 86, 189-199.

178. De Maria, R., Lenti, L., Malisan, F., d'Agostino, F., Tomassini, B., Zeuner, A., Rippo, M. R. \& Testi, R. (1997) Requirement for GD3 ganglioside in CD95- and ceramide-induced apoptosis, Nature $277,1652-1655$.

179. Suzuki, A., Iwasaki, M., Kato, M. \& Wagai, N. (1997) Sequential operation of ceramide synthesis and ICE cascade in CPT-11-initiated apoptotic death signaling, Exp. Cell Res. 233, 41-47.

180. Mizushima, N., Koike, R., Kohsaka, H., Kushi, Y., Handa, S., Yagita, H. \& Miyasaka, N. (1996) Ceramide induces apoptosis via CPP32 activation, FEBS Lett. 395, 267-271.

181. Dbaibo, G. S., Perry, D. K., Gamard, C. J., Platt, R., Poirier, G. G., Obeid, L. M. \& Hannun, Y. A. (1997) Cytokine response modifier $\mathrm{A}(\mathrm{CrmA})$ inhibits ceramide formation in response to tumor necrosis factor (TNF)- $\alpha$ : CrmA and Bcl-2 target distinct components in the apoptotic pathway, J. Exp. Med. 185, 481-490.

182. Sillence, D. J. \& Allan, D. (1997) Evidence against an early signalling role for ceramide in Fas-mediated apoptosis, Biochem. J. 324, $29-32$.

183. Watts, J. D., Gu, M., Polverino, A. J., Patterson, S. D. \& Aebersold, R. (1997) Fas-induced apoptosis of T cells occurs independently of ceramide generation, Proc. Natl Acad. Sci. USA 94, 72927296.

184. Liu, Z. G., Hsu, H., Goeddel, D. V. \& Karin, M. (1996) Dissection of TNF receptor 1 effector functions: JNK activation is not linked to apoptosis while NF- $\kappa$ B activation prevents cell death, Cell 87 , 565-576.

185. Natoli, G., Costanzo, A., Ianni, A., Templeton, D. J., Woodgett, J. R., Balsano, C. \& Levrero, M. (1997) Activation of SAPK/JNK by TNF receptor 1 through a noncytotoxic TRAF2-dependent pathway, Science 275, 200-203.

186. Beyaert, R., Cuenda, A., Vanden Berghe, W., Plaisance, S., Lee, J. C., Haegeman, G., Cohen, P. \& Fiers, W. (1996) The p38/RK mitogen activated protein kinase pathway regulates interleukin-6 synthesis response to tumor necrosis factor, EMBO J. 15, 19141923.

187. Cahill, M. A., Peter, M. E., Kischkel, F. C., Chinnaiyan, A. M., Dixit, V. M., Krammer, P. H. \& Nordheim, A. (1996) CD95 (APO-1/Fas) induces activation of SAP kinases downstream of ICE-like proteases, Oncogene 13, 2087-2096.

188. Juo, P., Kuo, C. J., Reynolds, S. E., Konz, R. F., Raingeaud, J., Davis, R. J., Biemann, H. P. \& Blenis, J. (1997) Fas activation of the p38 mitogen-activated protein kinase signalling pathway requires ICE/CED-3 family proteases, Mol. Cell Biol. 17, 2435 . 
189. Lenczowski, J. M., Dominguez, L., Eder, A. M., King, L. B., Zacharchuk, C. M. \& Ashwell, J. D. (1997) Lack of a role for Jun kinase and AP-1 in Fas-induced apoptosis, Mol. Cell Biol. $17,170-181$.

190. Ichijo, H., Nishida, E., Irie, K., ten Dijke, P., Saitoh, M., Moriguchi, T., Takagi, M., Matsumoto, K., Miyazono, K. \& Gotoh, Y. (1997) Induction of apoptosis by ASK1, a mammalian MAPKKK that activates SAPK/JNK and p38 signaling pathways, Science 275, 90-94.

191. Huang, S., Jiang, Y., Li, Z., Nishida, E., Mathias, P., Lin, S., Ulevitch, R. J., Nemerow, G. R. \& Han, J. (1997) Apoptosis signaling pathway in $\mathrm{T}$ cells is composed of ICE/Ced 3 family proteases and MAP kinase kinase 6b, Immunity 6, 739-749.

192. Nishina, H., Fischer, K. D., Radvanyi, L., Shahinian, A., Hakem, R., Rubie, E. A., Bernstein, A., Mak, T. W., Woodgett, J. R. \& Penninger, J. M. (1997) Stress-signalling kinase Sek1 protects thymocytes from apoptosis mediated by CD95 and CD3, Nature $385,350-353$.

193. Beyaert, R. \& Fiers, W. (1994) Molecular mechanisms of tumor necrosis factor-induced cytotoxicity. What we do understand and what we do not, FEBS Lett. 340, 9-16.

194. Wallach, D., Boldin, M., Varfolomeev, E., Beyaert, R., Vandenabeele, P. \& Fiers, W. (1997) Cell death induction by receptors of the TNF family: towards a molecular understanding, FEBS Lett 410, 96-106.

195. Kroemer, G. (1997) Mitochondrial control of apoptosis, Immunol. Today 18, 44-51.

196. Hirsch, T., Marchetti, P., Susin, S. A., Dallaporta, B., Zamzami, N., Marzo, I., Geuskens, M. \& Kroemer, G. (1997) The apoptosisnecrosis paradox. Apoptogenic proteases activated after mitochondrial permeability transition determine the mode of cell death, Oncogene 15, 1573-1581.

197. Leist, M., Single, B., Castoldi, A. F., Kuhnle, S. \& Nicotera, P. (1997) Intracellular adenosine triphosphate (ATP) concentration : a switch in the decision between apoptosis and necrosis, J. Exp. Med. 285, 1481-1486.

198. Laster, S. M., Wood, J. G. \& Gooding, L. R. (1988) Tumor necrosis factor can both induce apoptotic and necrotic forms of cell lysis, J. Immunol. 141, 2629-2635.

199. Matthews, N. \& Neale, M. L. (1987) Studies on the mode of action of tumor necrosis factor on tumor cells in vitro, Lymphokines $14,223-252$.

200. Schulze-Osthoff, K., Bakker, A. C., Vanhaesebroeck, B., Beyaert, R., Jacob, W. A. \& Fiers, W. (1992) Cytotoxic activity of tumor necrosis factor is mediated by early damage of mitochondrial functions. Evidence for the involvement of mitochondrial radical generation, J. Biol. Chem. 267, 5317-5323.

201. Schulze-Osthoff, K., Beyaert, R., Vandevoorde, V., Haegeman, G. \& Fiers, W. (1993) Depletion of the mitochondrial electron transport abrogates the cytotoxic and gene-inductive effects of TNF, EMBO J. 12, 3095-3104.

202. Jacobson, M. D., Burne, J. F., King, M. P., Miyashita, T., Reed, J. C. \& Raff, M. C. (1993) Bcl-2 blocks apoptosis in cells lacking mitochondrial DNA, Nature 361, 365-369.

203. Hug, H., Enari, M. \& Nagata, S. (1994) No requirement of reactive oxygen intermediates in Fas-mediated apoptosis, FEBS Lett. $351,311-313$.

204. Schulze-Osthoff, K., Los, M. \& Baeuerle, P. A. (1995) Redox signalling by transcription factors NF- $\kappa$ B and AP-1 in lymphocytes, Biochem. Pharmacol. 50, 735-741.

205. Wong, G. H. \& Goeddel, D. V. (1994) Fas antigen and p55 TNF receptor signal apoptosis through distinct pathways, J. Immunol. $152,1751-1755$.

206. Grell, M., Krammer, P. H. \& Scheurich, P. (1994) Segregation of APO-1/Fas antigen and tumor necrosis factor-mediated apoptosis, Eur. J. Immunol. 24, 2563-2566.

207. Cheng, J., Zhou, T., Liu, C., Shapiro, J. P., Brauer, M. J., Kiefer, M. C., Barr, P. J. \& Mountz, J. D. (1994) Protection from Fasmediated apoptosis by a soluble form of the Fas molecule, Science 263, 1759-1762.

208. Mysler, E., Bini, P., Drappa, J., Ramos, P., Friedman, S. M., Krammer, P. H. \& Elkon, K. B. (1994) The apoptosis-1/Fas protein in human systemic lupus erythematosus, J. Clin. Invest. 93, 10291034.
209. Knipping, E., Krammer, P. H., Lehman, T. J., Mysler, E. \& Elkon, K. B. (1995) Levels of soluble Fas/APO-1/CD95 in systemic lupus erythematosus and juvenile rheumatoid arthritis, Arthritis Rheum. 38, 1735-1737.

210. Sato, T., Irie, S., Kitada, S. \& Reed, J. C. (1995) FAP-1: a protein tyrosine phosphatase that associates with Fas, Science 268, 411-415.

211. Yanagisawa, J., Takahashi, M., Kanki, H., Yano Yanagisawa, H., Tazunoki, T., Sawa, E., Nishitoba, T., Kamishohara, M., Kobayashi, E., Kataoka, S. \& Sato, T. (1997) The molecular interaction of Fas and FAP-1. A tripeptide blocker of human Fas interaction with FAP-1 promotes Fas-induced apoptosis, J. Biol. Chem. 272, 8539-8545.

212. Cuppen, E., Nagata, S., Wieringa, B. \& Hendriks, W. (1997) No evidence for involvement of mouse proteine tyrosine phosphatase-Bas-like Fas-associated phosphatase-1 in Fas-mediated apoptosis, J. Biol. Chem. 272, 30215-30220.

213. Okura, T., Gong, L., Kamitani, T., Wada, T., Okura, I., Wei, C. F., Chang, H. M. \& Yeh, E. T. (1996) Protection against Fas/APO-1and tumor necrosis factor-mediated cell death by a novel protein, sentrin, J. Immunol. 157, 4277-4281.

214. Gong, L., Kamitani, T., Fujise, K., Caskey, L. S. \& Yeh, E. T. H. (1997) Preferential interaction of sentrin with a ubiquitinconjugating enzyme, ubc9, J. Biol. Chem. 272, 28198-28201.

215. Becker, K., Schneider, P., Hofmann, K., Mattmann, C. \& Tschopp, J. (1997) Interaction of Fas (APO-1/CD95) with proteins implicated in the ubiquitination pathway, FEBS Lett. 412, 102-106.

216. Thome, M., Schneider, P., Hofmann, K., Fickenscher, H., Meinl, E., Neipel, F., Mattmann, C., Burns, K., Bodmer, J. L., Schroter, M., Scaffidi, C., Krammer, P. H., Peter, M. E. \& Tschopp, J. (1997) Viral FLICE-inhibitory proteins (FLIPs) prevent apoptosis induced by death receptors, Nature 386, 517-521.

217. Hu, S., Vincenz, C., Buller, M. \& Dixit, V. M. (1997) A novel family of viral death effector domain-containing molecules that inhibit both CD95- and tumor necrosis factor receptor-1-induced apoptosis, J. Biol. Chem. 272, 9621-9624.

218. Bertin, J., Armstrong, R. C., Ottilie, S., Martin, D. A., Wang, Y., Banks, S., Wang, G. H., Senkevich, T. G., Alnemri, E. S., Moss, B., Lenardo, M. J., Tomaselli, K. J. \& Cohen, J. I. (1997) Death effector domain-containing herpesvirus and poxvirus proteins inhibit both Fas- and TNFR1-induced apoptosis, Proc. Natl Acad. Sci. USA 94, 1172-1176.

219. Peter, M. E., Medema, J. P. \& Krammer, P. H. (1997) Does the Caenorhabditis elegans protein CED-4 contain a region of homology to the mammalian death effector domain? Cell Death Diff. 4, 523-525.

220. Irmler, M., Thome, M., Hahne, M., Schneider, P., Hofmann, K., Steiner, V., Bodme, J. L., Schroeter, M., Burns, K., Mattmann, C., Rimoldi, D., French, L. E. \& Tschopp, J. (1997) Inhibition of death receptor signals by cellular FLIP, Nature 388, 190195.

221. Shu, H. B., Halpin, D. R. \& Goeddel, D. V. (1997) Casper is a FADD- and caspase-related inducer of apoptosis, Immunity 6 , $751-763$.

222. Hu, S., Vincenz, C., Ni, J., Gentz, R. \& Dixit, V. M. (1997) I-FLICE, a novel inhibitor of tumor necrosis factor receptor1- and CD95-induced apoptosis, J. Biol. Chem. 272, 1725517257.

223. Srinivasula, S. M., Ahmad, M., Ottilie, S., Bullrich, F., Banks, S., Wang, Y., Fernandes Alnemri, T., Croce, C. M., Litwack, G., Tomaselli, K. J., Armstrong, R. C. \& Alnemri, E. S. (1997) FLAME-1, a novel FADD-like anti-apoptotic molecule that regulates Fas/TNFR1-induced apoptosis, J. Biol. Chem. 272, $18542-18545$.

224. Goltsev, Y. V., Kovalenko, A. V., Arnold, E., Varfolomeev, E. E., Brodianskii, V. M. \& Wallach, D. (1997) CASH, a novel caspase homologue with death effector domains, J. Biol. Chem. 272, $19641-19644$.

225. Inohara, N., Koseki, T., Hu, Y., Chen, S. \& Núnez, G. (1997) CLARP, a death-effector domain-containing protein-interacts with caspase-8 and regulates apoptosis, Proc. Natl Acad. Sci. USA 94, 1017-10722.

226. Han, D. K. M., Chaudry, P. M., Wright, M. E., Friedman, C., Trask, B. J., Riedel, R. T., Baskin, D. G., Schwarz, S. M. \& Hood, L. 
(1997) MRIT, a novel death-effector domain-containing protein interacts with capsases and BclXL and initiates cell death, Proc. Natl Acad. Sci. USA 94, 11333-11338.

227. Peter, M. E., Kischkel, F. C., Scheuerpflug, C., Medema, J. P., Debatin, K. M. \& Krammer, P. H. (1997) Resistance of cultured peripheral $\mathrm{T}$ cells towards activation induced cell death involves a lack of recuitment of FLICE to the death-inducing signaling complex (DISC), Eur. J. Immunol. 27, 1207-1212.

228. Roy, N., Mahadevan, R. S., McLean, M., Shutler, G. \& Yaraghi, Z. (1995) The gene for neuronal apoptosis inhibitory protein is partially deleted in individuals with spinal muscular atrophy, Cell 80, 167-178.

229. Duckett, C. S., Nava, V. E., Gedrich, R. W., Clem, R. J., Van Dongen, J. L., Gilfillan, M. C., Shiels, H., Hardwick, J. M. \& Thompson, C. B. (1996) A conserved family of cellular genes related to the baculovirus iap gene and encoding apoptosis inhibitors, EMBO J. 15, 2685-2694.

230. Liston, P., Roy, N., Tamai, K., Lefebvre, C., Baird, S., Cherton Horvat, G., Farahani, R., McLean, M., Ikeda, J. E., MacKenzie, A. \& Korneluk, R. G. (1996) Suppression of apoptosis in mammalian cells by NAIP and a related family of IAP genes, Nature 379, 349-353.

231. Ambrosini, G., Adida, C. \& Altieri, D. (1997) A novel antiapoptosis gene, survivin, expressed in cancer and lymphoma, Nat. Med. 3, 917-921.

232. Shu, H. B., Takeuchi, M. \& Goeddel, D. V. (1996) The tumor necrosis factor receptor 2 signal transducers TRAF2 and c-IAP1 are components of the tumor necrosis factor 1 signaling complex, Proc. Natl Acad. Sci. USA 93, 13973-13978.

233. Deveraux, Q., Takahashi, R., Salvesen, G. S. \& Reed, J. C. (1997) $\mathrm{X}$-linked IAP is a direct inhibitor of cell death proteases, Nature 388, 300-303.

234. Roy, N., Deveraux, Q. L., Takahashi, R., Salvesen, G. S. \& Reed, J. C. (1997) The c-IAP-1 and c-IAP-2 proteins are direct inhibitors of specific caspases, EMBO J. 16, 6914-6925.

235. Bertin, J., Mendrysa, S. M., LaCount, D. J., Gaur, S., Krebs, J. F., Armstrong, R. C., Tomaselli, K. J. \& Friesen, P. D. (1996) Apoptotic suppression by baculovirus $\mathrm{P} 35$ involves cleavage by and inhibition of a virus-induced CED-3/ICE-like protease, J. Virol. $70,6251-6259$.

236. Xue, D. \& Horvitz, H. R. (1995) Inhibition of the Caenorhabditis elegans cell-death protease CED-3 by a CED-3 cleavage site in baculovirus p35 protein, Nature 377, 248-251.

237. Komiyama, T., Ray, C. A., Pickup, D. J., Howard, A. D., Thornberry, N. A., Peterson, E. P. \& Salvesen, G. (1994) Inhibition of interleukin- $1 \beta$ converting enzyme by the cowpox virus serpin CrmA, J. Biol. Chem. 269, 19331-19337.

238. Chu, Z. L., McKinsey, T. A., Liu, L., Gentry, J. J., Malim, M. \& Ballard, D. W. (1997) Suppression of tumor necrosis fator-induced cell death by inhibitor of apoptosis c-IAP2 is under NF$\kappa \mathrm{B}$ control, Proc. Natl Acad. Sci. USA 94, 10657-10621.

239. Reed, J. C. (1997) Double identity for proteins of the Bcl-2 family, Nature 387, 773-776.

240. Kroemer, G. (1997) The proto-oncogene Bcl-2 and its role in regulating apoptosis, Nat. Med. 3, 614-620.

241. Oltvai, Z. N., Milliman, C. L. \& Korsmeyer, S. J. (1993) Bcl-2 heterodimerizes in vivo with a conserved homolog, Bax, that accelerates programmed cell death, Cell 74, 609-619.

242. Boise, L. H., Gonzalez Garcia, M., Postema, C. E., Ding, L., Lindsten, T., Turka, L. A., Mao, X., Nunez, G. \& Thompson, C. B. (1993) Bcl-x, a bcl-2-related gene that functions as a dominant regulator of apoptotic cell death, Cell 74, 597-608.

243. Cheng, E. H., Levine, B., Boise, L. H., Thompson, C. B. \& Hardwick, J. M. (1996) Bax-independent inhibition of apoptosis by Bcl-XL, Nature 379, 554-556.

244. Clair, E. G. S., Anderson, S. J. \& Oltvai, Z. N. (1997) Bcl-2 counters apoptosis by Bax heterodimerization dependent and independent mechanisms in the T cell lineage, J. Biol. Chem. 272, $29347-29355$.

245. Simonian, P. L., Grillot, D. A., Andrews, D. W., Leber, B. \& Nunez, G. (1996) Bax homodimerization is not required for Bax to accelerate chemotherapy-induced cell death, J. Biol. Chem. $271,32073-32077$.
246. Simonian, P. L., Grillot, D. A. M. \& Nunez, G. (1997) Bak can accelerate chemotherapy-induced cell death independently of its heterodimerization with $\mathrm{Bcl}-\mathrm{X}_{\mathrm{L}}$ and $\mathrm{Bcl}-2$, Oncogene 15, 18711875.

247. Medema, J. P., Scaffidi, C., Krammer, P. H. \& Peter, M. E. (1998) Bcl- $X_{\mathrm{L}}$ acts downstream of caspase- 8 activation by the deathinducing signaling complex, J. Biol. Chem. 273, 3388-3393.

248. Monney, L., Otter, I., Olivier, R., Ravn, U., Mirzasaleh, H., Fellay, I., Poirier, G. G. \& Borner, C. (1996) Bcl-2 overexpression blocks activation of the death protease CPP32/Yama/apopain, Biochem. Biophys. Res. Commun. 221, 340-345.

249. Boulakia, C. A., Chen, G., Ng, F. W., Teodoro, J. G., Branton, P. E., Nicholson, D. W., Poirier, G. G. \& Shore, G. C. (1996) Bcl-2 and adenovirus E1B $19 \mathrm{kDA}$ protein prevent E1A-induced processing of CPP32 and cleavage of poly(ADP-ribose) polymerase, Oncogene 12, 529-535.

250. Susin, S. A., Zamzami, N., Castedo, M., Hirsch, T., Marchetti, P., Macho, A., Daugas, E., Geuskens, M. \& Kroemer, G. (1996) Bcl-2 inhibits the mitochondrial release of an apoptogenic protease, J. Exp. Med. 184, 1331-1341.

251. Pan, G., O'Rourke, K. \& Dixit, V. M. (1998) Caspase-9, Bcl- $\mathrm{X}_{\mathrm{L}}$, and Apaf-1 form a ternary complex, J. Biol. Chem. 273, 58415845.

252. Yang, J., Liu, X., Bhalla, K., Kim, C. N., Ibrado, A. M., Cai, J., Peng, T. I., Jones, D. P. \& Wang, X. (1997) Prevention of apoptosis by $\mathrm{Bcl}-2$ : release of cytochrome $c$ from mitochondria blocked, Science 275, 1129-1132.

253. Kluck, R. M., Bossy Wetzel, E., Green, D. R. \& Newmeyer, D. D. (1997) The release of cytochrome $c$ from mitochondria: a primary site for Bcl-2 regulation of apoptosis, Science 275, 11321136.

254. Zhivotovsky, B., Orrenius, S., Brustugun, O. T. \& Doskeland, S. O. (1998) Injected cytochrome $c$ induces apoptosis, Nature 391, 449-450.

255. Muchmore, S. W., Sattler, M., Liang, H., Meadows, R. P., Harlan, J. E., Yoon, H. S., Nettesheim, D., Chang, B. S., Thompson, C. B., Wong, S. L., Ng, S. L. \& Fesik, S. W. (1996) X-ray and NMR structure of human Bcl-xL, an inhibitor of programmed cell death, Nature 381, 335-341.

256. Schendel, S. L., Xie, Z., Montal, M. O., Matsuyama, S., Montal, M. \& Reed, J. C. (1997) Channel formation by antiapoptotic protein Bcl-2, Proc. Natl Acad. Sci. USA 94, 5113-5118.

257. Minn, A. J., Velez, P., Schendel, S. L., Liang, H., Muchmore, S. W., Fesik, S. W., Fill, M. \& Thompson, C. B. (1997) Bcl- $X_{L}$ forms an ion channel in synthetic lipid membranes, Nature 385, $353-357$.

258. Vander Heiden, M. G., Chandel, N. S., Williamson, E. K., Schumacker, P. T. \& Thompson, C. G. (1997) Bcl- $x_{L}$ reguates the membrane potential and volume homeostasis of mitochondria, Cell 91, 627-637.

259. Li, F., Srinavassan, A., Wang, Y., Armstrong, R. C. \& Tomaselli, K. J. (1997) Cell-specific induction of apoptosis by microinjection of cytochrome $c$, J. Biol. Chem. 272, 30299-30305.

260. Itoh, N., Tsujimoto, Y. \& Nagata, S. (1993) Effect of Bcl-2 on Fas antigen-mediated cell death, J. Immunol. 151, 621-627.

261. Mandal, M., Maggirwar, S. B., Sharma, N., Kaufmann, S. H., Sun, S. C. \& Kumar, R. (1996) Bcl-2 prevents CD95 (Fas/APO-1)induced degradation of lamin $\mathrm{B}$ and poly(ADP-ribose) polymerase and restores the NF- $\kappa \mathrm{B}$ signaling pathway, J. Biol. Chem. 271, 30354-30359.

262. Vanhaesebroeck, B., Reed, J. C., De Valck, D., Grooten, J., Miyashita, T., Tanaka, S., Beyaert, R., Van Roy, F. \& Fiers, W. (1993) Effect of bcl-2 proto-oncogene expression on cellular sensitivity to tumor necrosis factor mediated cytotoxicity, Oncogene 8, 1075-1081.

263. Memon, S. A., Moreno, M. B., Petrak, D. \& Zacharchuk, C. M. (1995) Bcl-2 blocks glucocorticoid- but not Fas- or activationinduced apoptosis in a T cell hybridoma, J. Immunol. 155, $4644-4652$.

264. Scaffidi, C., Fulda, S., Srinivasan, A., Friesen, C., Li, F., Tomaselli, K. J., Debatin, K.-M., Krammer, P. H. \& Peter, M. E. (1998) Two CD95 (APO-1/Fas) signaling pathways, EMBO J. 17, $1675-1687$. 
265. Jäättelä, M. (1993) Overexpression of major heat shock protein hsp70 inhibits tumor necrosis factor induced activation of phospholipase A2, J. Immunol. 151, 4286-4294.

266. Mehlen, P., Kretz Remy, C., Preville, X. \& Arrigo, A. P. (1996) Human hsp27, Drosophila hsp27 and human $\alpha \mathrm{B}$ crystallin expression mediated increase in glutathione is essential for the protective activity of these proteins against $\mathrm{TNF} \alpha$ induced cell death, EMBO J. 15, 2695-26706.

267. Baichwal, V. R. \& Baeuerle, P. A. (1997) Activate NF- $\kappa$ B or die? Curr. Biol. 7, R94-96.

268. Verma, I. M. \& Stevenson, J. (1997) I $\kappa$ B kinase: Beginning, not the end, Proc. Natl Acad. Sci. USA 94, 11758-11760.

269. Beg, A. A., Sha, W. C., Bronson, R. T., Ghosh, S. \& Baltimore, D. (1995) Embryonic lethality and liver degeneration in mice lacking the RelA component of NF- $\kappa \mathrm{B}$, Nature 376, 167-170.

270. Beg, A. A. \& Baltimore, D. (1996) An essential role for NF- $\kappa$ B in preventing TNF- $\alpha$-induced cell death, Science 274, 782-784.

271. Wang, C. Y., Mayo, M. W. \& Baldwin, A. S. J. (1996) TNF- and cancer therapy-induced apoptosis: potentiation by inhibition of $\mathrm{NF}-\kappa \mathrm{B}$, Science 274, 784-787.

272. Van Antwerp, D. J., Martin, S. J., Kafri, T., Green, D. R. \& Verma, I. M. (1996) Suppression of TNF- $\alpha$-induced apoptosis by NF$\kappa \mathrm{B}$, Science 274, 787-789.

273. Wu, M., Lee, H., Bellas, R. E., Schauer, S. L., Arsura, M., Katz, D., FitzGerald, M. J., Rothstein, T. L., Sherr, D. H. \& Sonenshein, G. E. (1996) Inhibition of NF- $\kappa \mathrm{B} / \mathrm{Rel}$ induces apoptosis of murine B cells, EMBO J. 15, 4682-4690.
274. Grilli, M., Pizzi, M., Memo, M. \& Spano, P. (1996) Neuroprotection by aspirin and sodium salicylate through blockade of NF$\kappa \mathrm{B}$ activation, Science $274,1383-1385$.

275. Grimm, S., Bauer, M. K. A., Baeuerle, P. A. \& Schulze-Osthoff, K. (1996) Bcl-2 downregulates the activity of transcription factor NF- $\kappa$ B induced upon apoptosis, J. Cell Biol. 134, 13-23.

276. Lin, K. I., Lee, S. H., Narayanan, R., Baraban, J. M., Hardwick, J. M. \& Ratan, R. R. (1995) Thiol agents and Bcl-2 identify an alphavirus induced apoptotic pathway that requires activation of the transcription factor NF- $\kappa$ B, J. Cell Biol. 131, 1149-1161.

277. Wong, G. H., Elwell, J. H., Oberley, L. W. \& Goeddel, D. V. (1989) Manganous superoxide dismutase is essential for cellular resistance to cytotoxicity of tumor necrosis factor, Cell 58, 923-931.

278. Krikos, A., Laherty, C. D. \& Dixit, V. M. (1992) Transcriptional activation of the tumor necrosis factor alpha-inducible zinc finger protein, A20, is mediated by kappa B elements, J. Biol. Chem. 267, 17971-17976.

279. Jäättelä, M., Mouritzen, H., Elling, F. \& Bastholm, L. (1996) A20 zinc finger protein inhibits TNF and IL-1 signaling, J. Immunol. $156,1166-1173$.

280. Opipari, A. W. J., Hu, H. M., Yabkowitz, R. \& Dixit, V. M. (1992) The A20 zinc finger protein protects cells from tumor necrosis factor cytotoxicity, J. Biol. Chem. 267, 12424-12427.

281. Song, H. Y., Rothe, M. \& Goeddel, D. V. (1996) The tumor necrosis factor-inducible zinc finger protein A20 interacts with TRAF1/TRAF2 and inhibits NF- $\kappa$ B activation, Proc. Natl Acad. Sci. USA 93, 6721-6725. 